Mesned İlahiyat Araştırmaları Dergisi / The Journal of Mesned of Theological Studies ISSN 2667-7075| e-ISSN 2687-3605 | https://dergipark.org.tr/tr/pub/mesned

Cilt (Vol.) 12 Sayı (Issue 2) Güz - (Autumn) 2021

ARAŞTIRMA MAKALESI | RESEARCH ARTICLE

(Bu makalenin intihal içermediği benzerlik tarama programlarıyla teyit edilmiştir. / The similarity that this article does not contain plagiarism, has been confirmed by plagiarism checker programs.)

Doi: $10.51605 /$ mesned.971646

Gönderim Tarihi: 14.06.2021 Kabul Tarihi: 24.12.2021

\title{
Metafizik Dönem Ekseninde Tasavvufun Teorik Yapısına Dair Doksografik Bir Değerlendirme
}

\author{
- A Doxographic Assessment of the Theoretical Structure of The Science of Sufism in \\ the Axis of the Metaphic Period-

\section{Güldane Gündüzöz ${ }^{*}$} \\ Atıf/Citation: Gündüzöz, Güldane. "Metafizik Dönem Ekseninde Tasavvufun Teorik Yapısına Dair \\ Doksografik Bir Değerlendirme / A Doxographic Assessment of the Theoretical Structure of The Science \\ of Sufism in the Axis of the Metaphic Period". Mesned Illahiyat Araştırmaları Dergisi/ The Journal of \\ Mesned of Theological Studies, (Güz 2021-2): 253-281.
}

Öz:

Tasavvuf tarihi özelinde fikrî ve kültürel açıdan çepeçevre kuşatılmış şartları derin bir okumaya tabi tutarak anlamaya çalıșmak, bu istikametteki metinleri anlamayı zorunlu kılmaktadır. Bu metinler, geçmiș dönemlerde pek çok dönemeci aşarak günümüze intikal etmiștir ve bunlar çeșitli şartlarda okunmuștur. Bin yılı aşan İslâm irfânı, çeșitli asırlarda yazılmıș pek çok irfânî metin ile bu zorunluluğu arastırmacıların omuzlarına yüklemektedir. İrfânî metinlerin iyice incelendikten sonra anlaşılabilmesi konusunda en önemli sorunlardan biri, irfânın ortaya çıkışı, meseleleri ve bir ilim olarak kültürel ve bağımsız bir yönelime nasıl girdiği ve elbette bu süreçte nasıl geliștiğinin anlaşılması problemidir.

Tasavvuf tarihi araștırmaları tasavvufî süreci iki ana gövdede mütalaa etmektedir. İbnü’l-Arabî'ye kadar olan ilk dönem, daha ziyade ahlâkî bir muhteva ve zühd yapısı içinde tezâhür eden bir dönemdir. Bu dönem teknik bir adlandırma ile fikh-ı bâtın olarak isimlendirilmektedir. İbnü'l-Arabî ile birlikte metafizik düsüncenin hâkim olduğu ve İbnü’l-Arabî ve takipçileri tarafından șekillendirilen ikinci dönemde, zühd ve ahlâk, bir metafizik düșünce sistemine dönüşmeye başlamıștır. Bu dönem ilm-i ilâhî, ilm-i tahkîk, ilm-i esrâr, tasavvuf metafiziği, tasavvuf felsefesi, felsefî tasavvuf, nazarî tasavvuf ve vahdet-i vücûd doktrini gibi isimlerle anılmaktadır. Bu durumda nazarî tasavvufu felsefeden ayıran nokta, tasavvufun seyr u sülûk ile olan kuvvetli bağıdır. Bir üstadın rehberliği olmadan bu yolu kat etmek zordur, üstadsız yola çıkmak, övülen bir is değildir. Cünkü yolun inceliklerini bilen bir üstad olmadan bu yola çıkmak, tehlikeli olabileceği gibi bazen elde edilecek sonuçlar bakımindan sınırlı da olabilir.

İmam Gazzâlî ve İbnü’l-Arabî'den önce metafizik tasavvufun hiyerarşik konumunu İbn Sînâ'nın belirlediği iddia edilmiștir. Fıkh-ı bâtın sonrası vahdet-i vücûd düșüncesinin yanı sıra İşrâkî geleneğin tasavvuf metafiziği içerisinde yer aldığını kabul etmek gerekir. Bu bağlamda Sühreverdî, İbn Sînâ'dan etkilenmiş bir sûfî olarak İbn Sînâ'ya ait bazı kavramları kullanmakta ve İbn Sînâ'nın kayıp Mașrık Hikmeti'ni aradığını, buna mukabil bu bilgiyi kendisinin bulduğunu ifade etmektedir. İşrâkî

Doç. Dr., Kırıkkale Üniversitesi İslami İlimler Fakültesi, guldanegunduzoz@kku.edu.tr. Orcid: 0000-0003-3007-6746. 
gelenekte tasavvuf metafiziği, daha ziyade "teellüh" kelimesi ile ifade edilir. "Teellüh”, ilâhiyat bilgisine mistik müșahede ile ulaşmanın yöntemi, "müteellih" ise metafizik gerçeklik hakkında kavramsal düșüncenin dișında ve ötesinde mistik bir vizyona sahip olan kimsedir. Burada Sühreverdî-i Maktûl, kendi doksografik tasnifini yaparak sekiz hakîm tipinin en başına "müteellih"i koymaktadır.

Teosofik düşüncenin gerçekten en derin irfân modelini, İbnü’l-Arabî ve onun öncülüğünde Sadreddîn Konevî gibi öğrencileri ortaya koymuşlardır. İbnü’l-Arabî’nin ifade ve yorumlarındaki harikulade kudret, günümüze kadar İslam irfân tarihinde eşi benzeri görülmemiş bir bakış açısı ortaya koymuştur. Ne var ki bu teori ile eş zamanlı ya da daha sonra ortaya konmuş ve birçok yönden birbirleriyle bağlantılı teorilerin varlığı inkâr edilemez. Üstelik bu teoriler, sadece tasavvufun kendi dinamikleriyle de açıklanamayacak kadar farklı düşünsel yapılarla irtibatlı görünmektedir. Bu noktada tasavvuf, kelâm ve felsefenin, bir tedahül oluşturacak şekilde benzer parametreleri kendi metodolojileri içerisinde șekillendirdikleri söylenebilir. Bu nazarî teșekkül süreci aynı zamanda disiplinler arası bir etkileşim sürecidir. Örneğin tasavvuf düşüncesini etkilemiş olan feyz nazariyesi Platon temelli bir referans zeminine sahiptir. Bu teori Aristo'nun düșünce dünyasına uymaz. Tasavvuf, İbn Sînâ üzerinden etkilendiği öngörülebilecek şekilde feyz nazariyesinden kendi neşvesi içerisinde yararlanmıștır. Ne var ki pek çok sûfî, tıpkı Yunus Emre'nin Divân-ı İlâhiyât'ında açıkça görüldüğü gibi Aristo'nun Anâsır-ı Erba'a düşüncesinden de beslenir.

Tasavvufun farklı tezâhür ve meşrepler ile bağlantılı olduğu kabul edilmelidir. Bu doğrultuda İşrâkî gelenek içerisinde İbnü'l-Arabî̀nin düşünce dünyasına oldukça yaklaşan Molla Sadrâ'nın vahdet-i sinhiyye yorumu ve teşkîk teorisi, -birtakım benzerliklerine rağmen- önemli ölçüde farklılıklar içeren tasavvufî yaklaşımlardır. Molla Sadrâ, âriflerin ve felsefecilerin felsefe ve irfân arasında gerek düşünce gerekse de dil bakımından bir eklektik yapı ve uyum konusundaki sarf ettikleri çabaları, nihâî kemal noktasına getirmiștir. O, İșrak Șeyhi'nin harcadığı gayretlerin boșa gitmesine müsaade etmemiş ve onun gayreti, sadece felsefe ile irfânı metot bakımından birleștirmekle kalmamış, bu durum, içeriği de ele alacak şekilde genişlemiştir. Nihayetinde zevkî ve şuhûdî metot ve vahdet-i vücûdun içeriği, felsefede de kabul gören bir konu haline gelmiştir ve Molla Sadrâ bunu felsefî bakımdan istidlalleri ile ortaya koyabilmiștir.

Fârâbî ve İbn Sînâ'nın feyz ve sudûr teorileri bağlamında ya da Anâsır-ı Erba'a gibi kozmogonik yaklaşımlarının, şu ya da bu şekilde varlık ve bilgi konusunda söyleyecek çok şeyi olan tasavvufa etkisinin olması yadırganacak bir durum değildir. Özellikle tasavvufun nazarî irfân boyutu açısından bilginin İslâmîleștirilmesi sürecinde bu menkul bilgi unsurları, nassî tevillere konu olacak şekilde içselleştirilmiştir.

Anahtar Kelimeler: Tasavvuf, İbn Sînâ, İbnü’l-Arabî, Sühreverdî-i Maktûl, Molla Sadrâ.

\section{Summary:}

Trying to understand the intellectual and culturally besieged conditions by subjecting them to a deep reading made it necessary to understand the texts in this direction in the history of Süfism. These texts have survived to the present day by overcoming many turns in the past, and they have been read under various conditions. Over a thousand years of Islamic wisdom puts this obligation on the shoulders of researchers with many scholarly texts written in various centuries. One of the most important problems in understanding the wisdom texts after they have been thoroughly studied is the problem of understanding the emergence of lore, its issues and how it entered into a cultural and independent orientation as a science and of course how it developed in this process.

Studies in the history of Sufism consider the Sufi process in two main bodies. The first period up to Ibn 'Arabī is rather a period that manifests itself in a moral content and a structure of asceticism. This period is called fiḳ al-bātin with a technical naming. metaphysical thought dominated with Ibn 'Arabī. Ibn 'Arabī which was shaped by him and his followers, asceticism and morality began to transform into a metaphysical thought system in this second period. This period is known by names such as 'ilm al-ilāhī, 'ilm al-tahkīk, 'ilm al-esrār, Sūfī metaphysics, philosophy of mysticism, philosophical mysticism, theoretical mysticism and Waḥdat al-Wudjūd. In this case, the point that distinguishes theoretical Suufism from philosophy is the strong connection of Șūfism with sayr wa sulūk. It is difficult to go this way without the guidance of a master, it is not a praiseworthy job to go without a master. Because, setting out on this road without a master who knows the details of the road can be dangerous and sometimes limited in terms of the results to be obtained. 
It has been claimed that Ibn Sīnā determined the hierarchical position of metaphysical mysticism before Imām al-Ghazālī and Ibn 'Arabī. It must be admitted that after fiḳh al-bāțin, the Ishrākī tradition took place in Șūfĩ metaphysics in addition to the idea of unity of existence. In this context as a Șūfî influenced by Ibn Sīnā, al-Suhrawardī used some concepts belonging to Ibn Sīnā. Suhrawardī claimed that Ibn Sīnā was looking for the lost hikma mashrikīya, but found this information himself. Ṣūfì metaphysics is rather expressed with "teellüh" in the Is of reaching the knowledge of theology through mystical observation, "müteellih" is someone who has a mystical vision of metaphysical reality outside and beyond conceptual thought. Here, Suhrawardī makes his own doxographic classification and puts "müteellih" at the top of the eight wise Șūfĩ types.

The truly profound model of gnosis of theosophical thought was put forward by Ibn 'Arabī and his students, such as Șadr al-Dīn al-Qūnawī. The marvelous power in Ibn 'Arabī's expressions and interpretations has brought an unprecedented perspective in the history of Islamic lore to this day. However, it is undeniable that there are theories that were put forward simultaneously with this theory or later and that are related to each other in many ways. Moreover, these theories seem to be related to different intellectual structures that cannot be explained only by the dynamics of Sunfism itself. At this point, it can be said that Șüfism, theology and philosophy have shaped similar parameters within their own methodologies to form a unity. This theoretical formation process is also an interdisciplinary interaction process. For example, the divine light theory, which has influenced mysticism, has a Plato-based reference ground. This theory does not fit Aristotle's world of thought. Sūfism has benefited from the divine light theory within the framework of its own systematic, which can be predicted to be influenced by Ibn Sīnā. However, many Șūfis are also fed by Aristotle's 'Anāṣir (four elements of the sublunar world) thought, just as it is clearly seen in Yūnus Emre's Dīwān.

It should be accepted that Șūfism is connected with different thought systems. In this direction, Mullā Șadrā's interpretation of unity of sinhiyyā and the theory of tashkīk, which is very close to the Ibn 'Arabī's thought in the Ishrāḳi tradition, are mystical approaches that contain significant differences, despite some similarities. Mullā Sadrā brought the efforts of sages and philosophers on an eclectic structure and harmony between philosophy and wisdom, both in terms of thought and language, to the point of final perfection. He did not let the efforts of Suhrawardi go to waste, his zeal not only combined philosophy and lore in terms of method, but expanded to include content as well. Ultimately, the emotional and spiritual method and the content of unity of existence became an accepted subject in philosophy and Mullā Șadrā was able to reveal this philosophically with his inferences. It is not strange that the approaches of al-Fārābī and Ibn Sīnā have an impact on Șūfism, which has a lot to say about existence and knowledge. In the process of Islamization of knowledge, especially in terms of the theoretical wisdom of Șufism, these movable knowledge elements have been internalized to be the subject of prose interpretations.

Keywords: Tasawwuf, Ibn Sīnā, Ibn 'Arabī, Suhrawardī al-Maḳtūl, Mollā Șadrā.

\section{GíRiș}

Tasavvuf tarihi araştırmaları tasavvufî süreci iki ana gövdede mütalaa etmektedir. Kuşkusuz farklı alt bölümlemeler yapmak mümkün olmakla birlikte bir bütün olarak İbnü'l-Arabî’ye (ö. 638/1240) kadar olan dönem, daha ziyade ahlâkî bir muhteva ve zühd yapısı içinde tezâhür eden bir dönem olması itibarryla zühd ve ahlâk tasavvufu denilebilecek bir mahiyet arz eder. Çeşitli meşruiyet tartışmalarına konu olan bu dönem, ahlâkî ve manevî hayat telakkisi olarak ilk nesle ait tasavvuf anlayışının daimî şekilde bir düşünce kriziyle birlikte 
anıldığına şahitlik eder. Bu dönem teknik bir adlandırma ile fıkh-ı bâtın olarak isimlendirilmektedir. ${ }^{1}$

Daha sonra metafizik düşüncenin hâkim olduğu ve İbnü'l-Arabî ve takipçileri tarafından şekillendirilen ikinci döneme ilişkin tasavvuf nazariyesi, zühd ve ahlâkın farklı bir metafiziğe evirilmesine şahitlik edecektir. Bu ise ilm-i ilâhî, ilm-i tahkîk, ilm-i esrâr, tasavvuf metafiziği, tasavvuf felsefesi, felsefî tasavvuf, nazarî tasavvuf ve vahdet-i vücûd doktrini gibi isimlerle anılmaktadır. ${ }^{2}$ Sûfîler bu çerçevede tasavvufun bu teorik boyutunu, ilm-i ilâhî ve mârifetullah gibi farklı adlarla da anmışlardır. Bu, İslâm filozoflarının kullandığı anlamıyla, metafiziktir [ilmü mâ ba'de't-tabî'a]. Ne var ki tasavvufu felsefeden ayıran nokta onda seyr u sülûkun olmasıdır. Ebû Nasr el-Fârâbî'nin (ö. 339/950) terminolojisinde ilm-i ilâhî, Ya`kub b. İshak el-Kindî’de (ö. 252/866 [?]) ise felsefe-i ûlâ olan metafizik, tasavvufta farklı bir derinlik ve yöntemle ele alınmıştır. Sadreddîn Konevî (ö. 673/1274) bu ilmi, mârifetullah, ilm-i Rabbânî, ilm-i hakâik, tahkîk ve ilm-i tahkîk diye isimlendirmektedir. Konevî açısından metafizik bilgi sadece Tanrı hakkında bir bilgi değil, aynı zamanda Tanrı'nın neticesinde eşyanın mâhiyet ve hakikatlerine dair nihaî bilgiye ulaştıran bir bilgidir. ${ }^{3}$

İbn Sînâ (ö. 428/1037) sonrası İşrâkî geleneğin kurucu figürü Sühreverdî-i Maktûl (ö. 587/1191), en yüce bilgi (ilm-i a'lâ) diye andığı nazarî hikmetin k1sımları arasında ilm-i ilâhîyi de saymaktadır. Bu ilmin müfredatı dâhilinde ele alınan Zorunlu Varlık ve akıllar gibi hususların bir yönü ile madde ile ilişkisi olsa da bu ilmin konusunun Mutlak Varlık'ın kendisi olduğu ifade edilmektedir. ${ }^{4}$ Bu dönem, nazarî tasavvuf, felsefî tasavvuf, tasavvuf felsefesi ve metafizik düşünce gibi farklı isimlerle anılmaktadır. ${ }^{5}$

Gazzâlî (ö. 505/1111) ve İbnü'l-Arabî'den önce mârifetin ve irfânın başka bir deyişle metafizik tasavvufun hiyerarşik konumunu İbn Sînâ'nın belirlediği söylenmektedir. İbn Sînâ, ârifi, ilim ve amel konusunda zâhid ve âbidden üstün saymaktadır. Ona göre, "Ârif, zâhid ve âbid bir derviş" demek değildir. "Ârif, zühd ve ibadeti sayesinde kâmil hâle gelen bir filozof" gibidir. Bu kemal nihayet onu hakkın nûruna muttali kılar. ${ }^{6}$ Sühreverdî, İbn Sînâ'dan etkilenmiş bir sûfî olarak İbn Sînâ'ya ait bazı kavramları kullanmakta ve İbn Sînâ'nın kayıp

\footnotetext{
Ekrem Demirli, Sadreddin Konevî'de Bilgi ve Varlık (İstanbul: İz Yayıncılık, 2011), 10.

Abdullah Kartal, Tasavoufun Oluşumu Şeriat-Hakîkat İlişkisi (Bursa: Emin Yayınları, 2015), 33.

Demirli, Sadreddin Konevî'de Bilgi ve Varlık, 76, 77.

4 Şihâbüddîn Sühreverdî, et-Telvîhâtü'l-levhiyye ve'l-'arşiyye, nşr. Necefkulî Habîbî (Tahran: Iranian Institute of Philosofy, 2009), 174.

5 Ekrem Demirli, İbnü'l-Arabî Metafiziği (İstanbul: Sûfî Kitap, 2013), 8, 13.

6 Mirvet İzzet Bâlî, el-İtticâhü'l-İşrâkî, fî felsefeti İbn Sinnâ (Beyrut: Dârü'l-Cîl, 1414/1994), 365.
} 
Maşrık Hikmeti'ni aradığını, buna mukabil bu bilgiyi kendisinin bulduğunu ifade etmektedir. Fıkh-1 bâtın sonrası vahdet-i vücûd düşüncesinin yanı sıra İşrâkî geleneğin tasavvuf metafiziği içerisinde yer aldığını kabul etmek gerekir. Bilahare Molla Sadrâ'nın (ö. 1050/1641) ve takipçilerinin söz konusu metafiziğe katkısı düşünüldügünde bu düşünce geleneği tasavvufî irfân geleneğinin bir parçası kabul edilmelidir. İşrâkî gelenekte tasavvuf metafiziğii, daha ziyade "teellüh" kelimesi ile ifade edilir. Sühreverdî-i Maktûl, kendi doksografik tasnifini yaparak sekiz hakîm tipinin en başına "müteellih"i koymaktadır. "Teellüh", ilâhiyat bilgisine mistik müşahede ile ulaşmanın yöntemi, "müteellih" ise metafizik gerçeklik hakkında kavramsal düşüncenin dışında ve ötesinde mistik bir vizyona sahip olan kimsedir. ${ }^{7}$

Şiîlikte Safevî çağından itibaren tasavvuf ve sûfîler/sûfiyye kelimelerinden ziyade irfân ve urefâ kelimeleri kullanılmıştır. Safiyüddîn Erdebilî̀'ye (ö. 735/1334) dayanan Safevî hanedanının siyasî bakış açısına göre tasavvufun zihniyet ve âdetlerinde bir gevşeme olduğu düşüncesiyle Şî̂ çevrede tasavvuf ve sûfî kelimelerinin yerine irfân (mistik teosofi) ve urefâ (mistik teosoflar) kelimeleri ikame edilmiştir. ${ }^{8}$

Sünnî paradigma içerisinde de irfân ve mârifet kelimelerinin kavramsal delâleti ile -ideolojik ve mezhebî mütalaaların ötesinde- nazarî irfân adlandırması yapılabilir. Bu, Hücvîrî (ö. 465/1072 [?]), Kuşeyrî (ö. 465/1072), Herevî (ö. 481/1089), Gazzâlî, Necmüddîn Kübrâ (ö. 618/1221), İbnü'l-Arabî ve Konevî'den başlayarak, Sühreverdî-i Maktûl, Şemseddîn Şehrezûrî (ö. 687/1288 [?]), Mîr Dâmâd (ö. 1041/1631), Molla Sadrâ (ö. 1050/1641) ve Feyz-i Kâşânî'ye (ö. 1090/1679) doğru tüm tasavvuf metafiziği ile ilgilenmiş şahsiyetleri içine alan bir disiplinin adıdır.

\section{BİLGİ VE DEĞER PROBLEMİ ÜZERINDEN TASAVVUFUN TEORÍK DÖNÜŞÜMÜ}

İlk tasavvuf hareketleri, teorik konuları ele alan ilimlere bir tepki olarak gelişmiştir. Bu dönemde tasavvufun ana sorunu, Allah'a yaklaşmak ve O'nu sevmekti. İlk dönem tasavvufu, Ebû Nasr es-Serrâc (ö. 378/988), Kelâbâzî (ö.

7 İlhan Kutluer, "Hikmetü'l-İşrâk", Türkiye Diyanet Vakfı İslâm Ansiklopedisi (İstanbul: TDV Yayınları, 1998), 17/522.

8 Henry Corbin, İslâm Felsefesi Tarihi: İbni Rüşd'ün Ölümünden Günümüze, çev. Ahmet Arslan (İstanbul: İletişim Yayınları, 2017), 2/68, 108. 
380/990) ve Kuşeyrî gibi sûfîlerin görüşünü esas alarak yaygınlaşmıştır. ${ }^{9}$ Nazarî temellerden yoksun olan bu dönemin tasavvufî anlayışı, "nazariyatsız tasavvuf" olarak değerlendirilmekte ve "ibtidâî bir tasavvuf" sayılmaktadır. ${ }^{10} \mathrm{Ne}$ var ki ilk dönem zühd hayatının giderek ibadetlerin bâtınî anlam ve hikmetlerini anlamaya çalışan boyuta intikali, bir dereceye kadar fıkh-ı bâtın şeklinde -dinî hükümlerin zâhirî yönüyle ilgilenen fikıh ilminin yanında- eskiye göre daha derin bir tasavvufî perspektifin oluşması anlamına gelmiştir. Fakat bu durum yine de tasavvufun beklenen şekilde nazarî bir hüviyet kazanması için yeterli değildir. Bu yeni yaklaşım ilm-i esrâr, ilm-i ahvâl ve ilm-i mükâşefe gibi adlarla anılmakta ve keşf ve ilham metoduyla kalbî bilgi ve mârifete her zamankinden fazla vurgu yapmaktadır. Böylece çerçevesini sadece zühdün oluşturduğu ve yaklaşık iki asır boyunca devam eden bakış, yerini ilâhî ahlâkla bezenmeyle birlikte dinî hükümlerin bâtınî manaları ve kalpteki tesirleriyle ilgilenen ve nefsin hastalık ve afetlerini, bunların tedavisini tezkiye, tasfiye, mücâhede ve mükâşefe gibi nev-i şahsına münhasır metotlarla gerçekleştiren bir bakışa bırakmıştır. ${ }^{11}$ Dolayısıyla yukarıda ifade edilen nazariyatsız tasavvuf tanımlamasını, etraflı bir sistematikten yoksun bir teorik zeminin olmaması şeklinde kayıtlayarak kabul etmemiz gerekir.

İlk dönem nazarî irfânında ya da başka bir deyişle tasavvuf metafiziğinde hakikat kavramı kilit bir rol oynamış, yakîn, mârifet ve irfân gibi kavramlar bu eksende organize edilmiştir. Bu dönemde kuramsal boyuttaki irfân kavramı, amelî irfân diyebileceğimiz alandan ayrışmaya başlamıştır. Hâce Abdullah elHerevî'nin (ö. 481/1089) Menâzilü's-sâirîn'i bu yaklaşıma iyi bir örnektir. ${ }^{12}$

Amelî irfân, insanın nihaî kemale, fenâ makamına ve Hakk'ı müşâhedeye ulaşmak için yerine getirdiği kuralların ve riyâzete dair hâllerin sonucunda gerçekleşen kalbî amellere yönelik hususlardan müteşekkil bir ilim olarak değerlendirilmiştir. Menzillerin ve makamların aşılmasında bu ilimden istifade edilmiştir. Böylece amelî irfânın konusu, kalp ve onun hâlleridir. Bu itibarla o, insanı nihaî kemale ulaştıracak bir alanı ifade etmektedir. ${ }^{13}$ Ahmed el-Gazzâlî (ö. 520/1126) ve Rûzbihân el-Baklî (ö. 606/1209) gibi sûfîler bir aşk metafiziği geliştirmeye çalışmışlar ve tasavvufu bu çerçevede ele almışlardır. Rûzbihân el-Baklî insanî aşk ile ilahî aşkı bir ve aynı aşkın iki biçimi olarak görmüş ve bu

Demirli, İbnü'l-Arabî Metafiziği, 14, 15 .

10 Demirli, İbnü'l-Arabî Metafiziği, 21.

11 Abdurrezzak Tek, Tarihi Süreçte Tasavvuf ve Tarikatlar (Bursa: Bursa Akademi, 2016), 62.

12 Yedullah Yezdân Penâh, el-írfânü'n-nazarî mebâdiuhû ve usûluhĥ, çev. Alî Abbâs el-Mûsevî (Beyrut: Merkezü'l-Hadâre li't-Tenmiyeti'l-Fikri'l-İslâmî, 2016), 24.

13 Penâh, el-ìrfânü'n-nazarî, 70 . 
iki aşkı karşı karşıya getiren bir çileciliği reddetmesi ile önceki sûfîlerden ayrılmıştır. ${ }^{14} \mathrm{Ne}$ var ki ilâhî aşk kavramı bir ölçüde tasavvufî düşüncede mihver bir kavram olarak bütüncül bir yapı ortaya koymayı hedeflemiş olsa da İslâm düşüncesinde fıkıh, hadis, kelâm vb. şeklindeki bölünmüş yapıdan doğan krizi ilk aşma denemesinde olan kişi, ilâhî aşktan çok mârifet kavramına dayanacak olan İmam Gazzâlî olmuştur. O adeta muhtelif bilgi sistemlerini birleştirerek bir Fıkh-1 Ekber inşa etmek istemiştir. Ebû Hâmid el-Gazzâlî, bu projesini özellikle İhyâu ulûmi'd-dîn olmak üzere el-Munkiz mine'd-dalâl gibi eserleri ile gerçekleştirmeye çalışmıştır. Gazzâlî'nin ana problemi insanı dalâletten kurtaracak olanın ne olduğudur. Bu itibarla Gazzâlî̀nin tasavvuftan anladığı şey, ahlâk ve fıkh-1 bâtındır. ${ }^{15}$ Sünnî tasavvuf, Gazzâlî'den yüz ila yüz elli yıl önce Cüneyd-i Bağdâdî (ö. 297/909), hatta ondan da önce teşekkül etmiştir. Gazzâlî’nin eserleri, bu bakımdan bir sonuç sayılmalıdır. Gazzâlî̀nnin metafizik eleştirileri İbnü’1Arabî ve özellikle Konevî üzerinde etkili olmuştur. Gazzâlî ve İbnü'l-Arabî bütünlük ve küllî bilginin aranmasını amaç edinmişlerdir. ${ }^{16}$

Daha erken dönemde Hâris el-Muhâsibî (ö. 243/857) ve Cüneyd-i Bağdâdî gibi dinî ilimlerde otorite kabul edilen bazı âlimlerin tasavvufa intisap etmeleri tasavvufun meşruiyet iddiası açısından son derece olumlu bir gelişme olmuştur. Gerek sözleri gerekse hayatları itibarıyla Ehl-i sünnet çizgisindeki mutasavvıflar, bir sonraki asırda Serrâc, Kelâbâzî, Kuşeyrî ve Hücvirî gibi müellifleri tasavvufun dinî ilimlerdeki yerini belirlemeye sevk etmiştir. Onların bu çabaları tasavvufun Ehl-i sünnet içinde teşekkülünü hızlandırmıştır. ${ }^{17}$ Gazzâlî ise bunu bir daha geri dönülmez şekilde gerçekleştirmiştir.

Tasavvuf tarihinde hicrî üçüncü ve dördüncü yüzyıl, -sağlam bir teorik çerçeveye oturmasa bile- kendisinden önceki asırların birikimini tevarüs ederek ileriye dönük teorileri besleyen bir dönemdir. Bu dönemde Hâris el-Muhâsibî, Zünnûn el-Misrî (ö. 245/859 [?]), Bâyezîd-i Bistâmî, Cüneyd-i Bağdâdî ve Hallâc-1 Mansûr (ö. 309/922) gibi önemli şahsiyetler yetişmiştir. Beşinci yüzyılda gelişen terminoloji ve zenginleşen literatür göze çarparken altıncı ve yedinci yüzyıllarda Kâdiriyye ve Rifâiyye tarikatları gibi daha örgütlü ve yaygın tasavvufî tarikatlar ortaya çıkmıştır. Yedinci yüzyılda tarikatlar daha da çoğalmış, Ebü'l-Hasen eş-Şâzelî̀nin (ö. 656/1258) Şâzeliyye'si, Ahmed el-Bedevî'nin (ö.

14 Corbin, İslâm Felsefesi Tarihi, 2/69.

5 Demirli, İnü̈l-Arabî Metafiziği, 23.

6 Demirli, İbnü'l-Arabî Metafiziŭi, 25.

17 Ekrem Demirli, "Gazzâli ve Tasavvuf”, Gazzâlî Konuşmaları, (İstanbul: Küre Yayınları, 2012), 270271; Tek, Tasavvuf ve Tarikatlar, 236. 
675/1276) Bedeviyye'si, İbrahim b. Abdülazîz ed-Desûkî'nin (ö. 676/1277) Desûkiyye'si önceki oluşumları izlemiştir. ${ }^{18}$

Gazzâlî öncesi Serrâc, Ebû Tâlib el-Mekkî (ö. 386/996), Kelâbâzî, Hücvîrî ve Abdülkerîm Kuşeyrî gibi mutasavvıflar, tasavvufun meşruiyeti problemini, onun şer'î bir ilim müfredatı ile organize edilmesi ve tasavvufa ait kavramsal alanın nassî referanslarla istişhâd edilmesi ile aşmaya çalışmışlardır. Sûfîler daha ilk baştan beri tasavvufî bilgiye miyar bulmanın önemli bir problem olduğunu anlamışlardır. Cüneyd-i Bağdâdî, Ebû Nasr Serrâc, Ebû Tâlib el-Mekkî, Kuşeyrî ve Kelâbâzî gibi isimler, bu sorunu Sünnî tasavvuf anlayışıyla çözmek istemişlerdir. Bu anlayışta tasavvuf, Ehl-i sünnet akidesi ve fıkıh ilkelerini kabul eden bir bâtınî fıkıh veya ahlâk olarak yorumlanmıştır. Gazzâlî'nin elMunkız'da tasavvufu "kurtarıcı bilim" olarak müjdelemesi bu anlayışın bir neticesidir. İbnü'l-Arabî ve Sadreddîn Konevî ise tasavvufa miyar bulma işini daha evrensel bir dille yapmak istemişlerdir. Bunun anlamı, konusunun, problemlerinin ve ilkelerinin tespit edilerek tasavvufun kesin bir ilim olarak ortaya konulmasıdır. ${ }^{19}$

İbnü'l-Arabî öncesindeki tasavvufî döneme ilişkin meşruiyet krizinin boyutunu anlamak için bâtın fıkıh döneminden İbnü'l-Arabî'ye doğru geçişi temsil eden Gazzâlî iyi incelenmelidir. Gazzâlî, zühd ve ahlâk ekseninde İslâmî ilimler arasında tasavvufa meşruiyet kazandırmak için mârifet olgusunu oldukça teferruatlı şekilde ele almıştır. Fıkh-ı bâtın döneminde kapsamlı bir teşebbüsün mimarı olan Gazzâlî, sorunu akide ve ahlâk eksenli bir bilgi organizasyonu olarak görmüştür. Allah-âlem ilişkisini şerh ve izah eden ve bir yönü tecrübî olan her türlü ontolojik ve epistemolojik bilgi, Gazzâlî̀ye göre irfân ilminin müfredatına girmektedir. Hatta ona göre bu hâl, "Ene'l-Hak", "Subhânî mâ a'zame şânî" ve "Mâ fî cübbetî illallâh" makamı olsa da böyledir. ${ }^{20}$

Gazzâlî, açılamalarında hakikat ve mârifet kavramlarına dayanmaktadır. Bu suretle Gazzâlî, Mişkât ayetini açıklarken Nûr-1 Muhammedî’yi tarif etmekte ve "Hakîkatü'l-hakâik" ifadesini kullandığı satırlarda "Allah'ın vechinden başka her şeyin helak olacağını" ifade eden ayete (Kasas, 28/88) atıfla tek ve hak olanın Allah'ın varlığından başkası olmadığını ifade etmektedir. Ârifler hakikatin semâsına eriştiklerinde tecrübî olarak bu kanaati izhar etmek-

18 Esmâ Havâlidiyye, Sar'a't-tasavouf, el-Hallâc ve 'Aynu'l-Kudât el-Hemezânî ve's-Sühreverdî nemâzice: dirâsetün tahlîliyye nakdiyye mukârene testelhimu mefâhîme nazariyyeti't-takabbül (Rabat: Dâru'lEmân, 1435/2014), 59-60.

19 Ekrem Demirli, Tasavoufun Altın Çă̆̆: Konevî ve Takipçileri (İstanbul: Sufi Kitap, 2015), 31.

20 Ebû Hâmid el-Gazzâlî, Mişkâtü̈l-envâr ve misfâtü'l-esrâr, thk. Abdülaziz İzzüddîn es-Seyravân (Beyrut: Âlemü'l-Kütüb, 1407/1986), 138-139. 
te hemfikirdirler. Gazzâlî, irfân terminolojisinde bu temel ilkeye ulaşmanın irfânî ilim ya da zevkî hâl olarak tavsif edildiğini söylemektedir. ${ }^{21} \mathrm{O}$ hâlde Gazzâlî'nin tasavvufa dair projesi ahlâk temeline dayalı epistemolojik bir paradigma inşası olarak tanımlanabilecekken, Sadreddîn Konevî ontolojik bir paradigma inşa etmektedir. ${ }^{22}$

Ebû Hâmid el-Gazzâlî "imâm" ve "hüccetü'l-İslâm" gibi unvanlarla anılmış, devlet tarafından otoritesi tescil edilmiş bir şahsiyettir. O, Şî̂ ve Bâtınî irfânına karşı Sünnî bir nazarî irfân modeli sunmaktadır. Gazzâlî ve Aynülkudât el-Hemedânî (ö. 525/1131) arasında bir halef selef ilişkisi olduğu da söylenebilir. Alexander D. Kynish'in görüşü doğrultusunda denilebilir ki Gazzâlî'nin yeni Eflatunculuğa karşı bir figür olarak sunulması, çok doğru olmayan ve farklı problemlerin doğmasına yol açacak bir yaklaşımdır. Aslında Gazzâlî’nin yaptığı, feyz nazariyesi ile ulemanın varlık anlayışını birleştirmeye matuf bir fikrî yapıyı işaret etmektedir. ${ }^{23}$ Gazzâlî, Cüneyd-i Bağdâdî ve Kuşeyrî'nin tasavvuf metodolojisinin inşasındaki etkinliklerinin yanında zâhir ve bâtın alanını birbirine yaklaştırmada ve tasavvufa yönelik birtakım tenkitleri bertaraf ederek meşru bir bilimsel zemin ve metodoloji oluşturmada öncü bir şahsiyettir. ${ }^{24}$

İfade edildiği üzere Metafizik tasavvufun öne çıktığı ikinci dönem, İbnü'l-Arabî ve onun nazarî irfâna dair eserleri ile başlayan dönemdir. Bu dönemde nazarî irfân ya da tasavvuf metafiziği, varlığı anlamada tam olarak sistematik bir alan hâline gelmiştir. Sistemin temel yapısı, vahdet-i vücûd teorisi ve şuhûd ilkesidir. Ontolojik unsurları ve metafizik boyutu elbette saklı tutularak daha dar anlamda "Nazarî irfân, riyâzet yönü dikkate alınarak ârifin riyâzet ve aşk sebebiyle kendisinde husûle gelen ve merhalelerinin en sonunda şuhûd sayesinde ulaştığı varlığın (vücûdun) vahdet-i şahsiye'si ve gereklerini ve tevhidî hakîkat ve mârifetleri ifade eden bir ilimdir." 25 şeklinde tanımlanabilir.

Öncesinde Sühreverdî-i Maktûl'un bulunduğu ve asıl itibarıla daha geç dönemde Molla Sadrâ'nın ortaya çıkışıyla başlayan süreç ise nazarî irfânın faklı bir damarı ya da tasavvuf metafiziğin değişik bir neşvesi olarak kabul edilebilir. Bu dönemeçte başka sûfîler de vardır. Bunlardan biri yaşadığı dönemde Orta

21 Seyyid Şerîf el-Cürcânî, Kitâbu't-ta'rîfât: Arapça-Türkçe Terimler Sözlüğ̈̈, çev. Ali Erkan (İstanbul: Bahar Yayınları, 1997), 154.

22 Penâh, el-ìrfânü'n-nazarî, 33.

23 Alexander D. Knysh, Ibn Arabī in The Later Islamic Tradition The Making of a Polemical Image in Medieval Islam (New York: State University of New York Press, 1999), 339.

24 Ekrem Demirli, İbnü'l-Arabî Metafiziği, 25.

25 Penâh, el-írfânü'n-nazarî, 71. 
Asya tasavvufuna hâkim olan Necmüddîn Kübrâ'dır. Onun öğrencilerinin, İbnü'l-Arabî'nin öğrencileri ile karşılaşması, Doğu'daki İslâm'ın manevî geleceği için büyük ve belirleyici bir olaydır. Kendisi de tecrübî bir nûr mistisizmi öğretisine sahip olan Necmüddîn Kübrâ'nın öğrencileri ile İbnü'l-Arabî'nin öğrencilerinin karşılaşmasının geometrik izdüşümünde, Sühreverdî'nin “Doğu Nûr Teosofisi" bulunur. Necmüddîn Kübrâ'nın şehit edilmesiyle birlikte tarikatında bulunan bir grup, Alâüddevle-i Simnânî (ö. 736/1336) liderliğinde "Rükniyye" adlı bir kol oluşturmuştur. ${ }^{26}$ Alâüddevle-i Simnânî, onun "Nûr İnsanı Fizyolojisi"ni geliştirerek bunu muhteşem bir kozmogoni ve kozmoloji şeması içine yerleştirmiştir. ${ }^{27}$

\section{MEŞŞÂîlLIKTTEN İŞRÂKİLİĞE GEÇIŞ VE İBN SİNÂ'NIN TASAVVUF DÜŞÜNCESINE KATKILARI}

Hikmet-i Maşrık'ın mahiyeti, tasavvuf metafiziği tartışmaları açısından önem arz etmektedir. Zira gerek İbn Sînâ'nın gerekse de Sühreverdî-i Maktûl'ün bunu kendilerine referans aldıklarına dair atıfları bulunmaktadır. Bu geleneği Konevî düşüncesi ile birleştirmiş olan Kutbeddîn eş-Şirâzî (ö. 710/1311), işrâk ya da gnostik bilgi olarak ma'rifet-i maşrıkiyye'nin, -başka bir deyişle- işrâka dayalı hikmetin temel enstrümanı olarak keşfî bilgiyi görmektedir. Bu anlamda hikmetü'l-meşârıka büyük ölçüde kadim İran felsefesidir. Zira bu felsefe genel itibarıyla keşfî ve zevkî olup tecerrüd hâlinde nefiste aklî nûrların ve bunlara ait parıltı ve feyezânın zuhûru ilkesine dayanmaktadır. ${ }^{28}$

Mâcid Fahrî'nin dikkat çektiği üzere, İbn Sînâ'nın işrâk düşüncesinde bazı bilgiler ancak sûfî tecrübesine dayalı olarak elde edilebilir. Bu görüş, temel olarak Hay b. Yakzân hikâyesinde temsil edilmektedir. Buna göre şark/maşrık, "tenezzülü'l-envâr", yani nurların inmesini ve aydınlanmayı sembolize ederken, garb/mağrib karanlığı ifade etmektedir. ${ }^{29}$ Bu noktada Kur'ânî bazı argümanlara da başvurulmuştur. Sûfîler ve tecrit yanlısı İslâm düşünürleri "Allah her kime bir nûr bahşetmezse onun için nûr söz konusu olamaz" (Nûr, 24/40) ayetini referans almışlardır. ${ }^{30}$

26 Abdulhüseyin Zerrinkub, Tarihsel Perspektifiyle Iran Tasavvufu, çev. Nurcan Altun (İstanbul: Önsöz Yayıncılık, 2014), 61.

27 Corbin, İslâm Felsefesi Tarihi, 2/86, 90.

28 Bâlî, el-ïtticâhü'l-İşrâkî, 39.

29 Mâcid Fahrî, Târîhu'l-felsefeti'l-İslâmiyye (Beyrut: ed-Dâru'l-Muttehide li'n-Neşr, 1974), 401.

30 Penâh, el-ìrfânü'n-nazarî, 98. 
Felsefeciler arasında tasavvufa bir sûfîden daha çok yönelen İbn Sînâ'dır. $\mathrm{Bu}$ itibarla onun felsefesinin Aristotelesçi olduğunu söylemek güçtür. O, büyük ölçüde İrfaniyecilik ve Hermetizm'den etkilenmiştir. Âlemin var ediliş keyfiyeti muhtelif açıklamalara sahne olmuştur. Bu kapsamda feyz nazariyesi, doğrudan yaratma ve ihtirâ' olgusu yanında en kuvvetli nazariyelerden biri olarak İslâm düşüncesinin kendine özgü referansları çerçevesinde etkili olmuştur. Bu husus farklı teviller doğrultusunda ele alınmıştır. Bir ölçüde temelleri Plotinus'a kadar uzanan feyz nazariyesi, âlemin yaratılması konusunda Maşrık filozoflarının çözümü olarak görülmüş, İslâm düşüncesinde Ebû Nasr el-Fârâbî (ö. 339/950) ve İbn Sînâ da bu nazariyeden etkilenmiştir. Buna göre "aşk", varlığın mahiyetinin hakikatinde bulunmaktadır. Diğer bir deyişle Hayr-ı Mahz'ın mahiyeti aşktır. Dolayısıyla İbn Sînâ düşüncesinde aşk aynı zamanda ontolojik bir gerçekliktir. ${ }^{31}$

Kuşkusuz İslâm düşüncesinde varlık ve bilgi teorileri bakımından temel Kur'ânî referanslardan biri, Mişkât ayetidir (Nûr, 24/35). İslâmî düşüncede feyz nazariyesinin ilk önemli temsilcilerinden biri olan İbn Sînâ, Mişkât ayetini kullanmak suretiyle felsefî bir âlem tasavvuru geliştirmiştir. Bu onun, senkretik bilginin İslâmîleştirilerek İslâm düşüncesinin kendi iç dinamikleri ile harmanlanması ve ontolojik ve epistemolojik bir varlık modeli inşası konusundaki çabalarının bir sonucudur. İbn Sînâ'ya göre Âlemü'l-Kuds ile ittisâl, ârif için bir idealdir. ${ }^{32}$ İbn Sînâ, ontoloji ile ilahî aşk metafiziği arasında organik bir bağ kurmaktadır. İbn Sînâ'ya göre her varlık, yokluk ile varlık arasındaki boşluk ve yokluktan doğan (heyûlânî ve 'ademî) kötülükten ve kendisine ait eksiklikten kaçış durumundadır. Buna göre her kötü olan şey, heyûlâ ve 'adem ile bağlantılıdır. Bu doğrultuda her müdebber varlığın tabiî bir şevk ve garîzî bir aşka sahip olduğu aşikârdır. ${ }^{33}$

İlâhî aşka bağlı Allah tasavvuru, tasavvufî yorumlarda farklı tonlarda kendini göstermektedir. "Kâdir-i Mutlak Tanrı" anlayışına kıyasla aşk ve merhamet eksenindeki söz konusu teolojik yorum, giderek daha çok Kenz-i Mahfî kudsî hadisi çerçevesinde derinlik kazanmış ve Allah ile âlem arasındaki irtibatı izah noktasında önemli bir model olmuştur. ${ }^{34}$

\footnotetext{
Bâlî, el-İtticâhü'l-İşrâkî, 223, 418, 461.

Bâlî, el-ítticâhü'l-İşrâkî, 268.

33 İbn Sînâ, Risâle fi'l-'ışk, thk. Hüseyin es-Sıddîk-Râviye Câmûs (Dımaşk: Dâru'l-Fikr, 2005), 49, 54$55,57,58$.

34 Henry Corbin, Bir'le Bir Olmak: İbn Arabî Tasavoufunda Yaratıcı Muhayyile, çev. Zeynep Oktay (İstanbul: Pinhan Yayınları, 2015), 110; Henry Corbin, el-Hayâlu'l-Hallâk fî̀ tasavoufi Ibn Arabî, çev. Ferîd ez-Zâhî (Bağdat-Köln: Menşûrâtü'l-Cemel, 2008), 131.
} 
“Gazzâlî, Mişkâtü̈l-envâr adlı eserinde aynı ayeti yorumlayarak İbn Sînâ etkisiyle ruhun mertebelerine açılklk getirmiştir. Sühreverdî-i Maktûl'ün kurduğu İşrâk felsefesinde de Mişkât ayetine yönelik yorumların önemli bir yeri vardır. Dolayısıyla nûr metafiziğine dayanan bu düşüncenin temellerini, İbn Sînâ'nın Hay b. Yakzân, Salaman ve Absâl ve Risâletü't-tayr gibi sembolik eserlerinde, İşârât'ının son bölümlerinde (makâmâtü'l-ârifîn), benzer şekilde Gazzâlî'nin Mişkâtü'l-envâr, İbn Tufeyl'in Hay b. Yakzân adlı eserlerinde ve muhtelif tasavvufî eserlerde bulmak mümkündür.

\section{NAZARÎ İRFANIN ÜÇ TEMEL EKOLÜ VE METAFIZİK DÖNEM: SÜHREVERDÎ, İBNÜ'L-ARABî VE MOLLA SADRÂ}

Nazarî irfân ya da bir başka deyişle tasavvuf metafiziğinin üç önemli damarının temsilcileri olarak Sühreverdî-i Maktûl, İbnü'l-Arabî ve Molla Sadrâ zikredilmelidir. ${ }^{35}$

\subsection{Sühreverdî-i Maktûl}

Meşşâ̂ felsefesinin merkezi olan Isfahan'da Sühreverdî'nin, İbn Sînâ ekolü ile doğrudan iletişimi olmuş ve İbn Sînâ'nın Risâletü't-tayr'ını Arapçadan Farsçaya çevirmiştir. ${ }^{36}$ İbn Sînâ'nın el-İ̧sârât'ına bir şerh de yazmış olan Sühreverdî, gençlik yıllarında Meşşâilik ile iç içe olan bir çevrede yaşamıştır. Mardin'e yaptığı yolculuk esnasında sürekli Meşşâi felsefesine inanan hocalarla birlikte olduğu kayıt altında olan ${ }^{37}$ Sühreverdî, bir süreliğine Anadolu'ya geçmiş, Diyarbakır'da ikamet etmiş̧ir. ${ }^{38}$ Onun Selçuklu sarayında bir İşrâkî okulu açtığ 1 da kaydedilir. ${ }^{39}$ Sühreverdî Halep'e yerleştikten sonra dönemin fakihleriyle bazı hususlarda karşı karşıya gelmiş, siyasî şartlar aleyhine olunca idama mahkûm olmuştur. ${ }^{40}$

35 İbnü'l-İmâd el-Hanbelî, Şezerâtü'z-zeheb fî ahbâri men zeheb (Kahire: Mektebetü'1-Kudsî, 1350), 4/290; Yasin Hüseyin el-Veysî, es-Sühreverdî el-İşâkî ve nakduhû li'l-felsefeti'l-Yûnâniyye (Dimeşk: Dârü Ninova, 2007), 29; Abdurrahmân Bedevî, Şahsiyyât kalika fi'l-İslâm (Beyrut: el-Merkezü'lAkâdîmî, li'1-Ebhâs, 2015), 160.

36 Muhammed Alî Ebû Reyyân, Usûlü'l-felsefeti'l-İşrâkiyye inde's-Sühreverdî (Beyrut: Dârü'nNahdati'l-Arabiyye, ty), 12.

37 Ebü'l-Abbâs Şemsüddîn Ahmed İbn Hallikân, Vefeyâtü'l-a'yân, thk. İhsan Abbas (Beyrut: Dârü Sâdır, ty), 2/348.

38 Veysî, es-Sühreverdî, 30-31.

39 Ebû Reyyân, Usûlü'l-felsefeti'l-İşrâkiyye, 14.

40 Ebû Reyyân, Usûlü'l-felsefeti'l-İşrâkiyye, 16; Bedevî, Şahsiyyât kalika fi'l-İslâm, 162. 
Sühreverdî'nin yaşadığı dönemin, İsmâilî ve Bâtınî oluşumlara karşı Sünnî düşünce dünyasının mücadelesine sahne olduğu hatırlanacak olursa konjonktürel durumun, İşrâkîlik'teki sembolizm ve irfânî alegorik dilin inşasında etkili olduğu fark edilir. O hâlde bu düşünce sistemini iç dinamikler kadar, haricî unsurların tayin ve tespit ettiğini söylemek abartılı bir yaklaşım olmaz.

Sühreverdî önceki filozoflarla kıyas kabul etmeyecek şekilde şuhûdu ve müşâhedeyi istidlâlin yanında temel bir kaynak olarak kabul etmektedir. O, bunu yaparken Meşşâ̂i felsefeyi ve temsilcilerini ötekileştirmeden yapmaya çalışır. Sühreverdî, Aristo'yu -eleştirmekle beraber- onu kendi düşüncesinin temel referanslarından biri olarak değerlendirmektedir. Sühreverdî, Misır ve İran kadim bilgeliğine yaptığı güçlü atıflara rağmen İslâm'daki hikmeti, Sehl etTüsterî (ö. 283/896), Zünnûn el-Mısrî (ö. 245/859 [?]), Bâyezîd-i Bistâmî ve Hallâc-1 Mansûr'a bağlamaktadır. ${ }^{41} \mathrm{O}$, Hikmetü'l-işrâk'ın girişinde nûrlar ilminin ('ilmü'l-envâr) tecrübeye (zevk) dayandığını ve bu tecrübeleri yaşayan Platon (m.ö. 427-347) öncesindeki kadim filozofların (Hermes, Empedokles, Pisagor vd.) sözlerinin sembolik olduğunu belirtmektedir. Ferşâvşîr ve Bozorgmehr gibi Fars bilgelerinin yolu olan Doğu öğretisi (kâ'idetü'ş-şark) nûr ve zulmet üzerine kuruludur. Sühreverdî bu iki tarzı ve iki yolu birleştirmiştir. Onun yöntemi, müşâhede/tecrübe/zevk, dili ise sembolik olan bir felsefedir. ${ }^{42}$

Sühreverdî, gnostik bilgi anlayışıyla aklî nurlar kavramının, tasavvuf ehline, müteâl olan varlıkları doğrudan bilme gücü vermesine göndermede bulunmakta, böylece aklın yanında keşf ve sezgiyi bir idrak vasıtası olarak görmektedir. ${ }^{43}$ Sühreverdî, Platoncu ve Aristocu felsefe ile İslâm tasavvuf ruhunu harmanlamış ve bir yönüyle rasyonel, diğer yönüyle zevk ve keşfe dayalı bir irfân nazariyesi ortaya koymaya çalışmıstır. ${ }^{44}$ Sühreverdî, ortaya koyduğu bu halîtaya rağmen eklektik bir felsefî anlayıştan ziyade, nazarî ilim ile teellüh adını verdiği sûfî zevki arasında şekillenmiş bir işrâkî düşünce sistematiği geliştirmeyi amaçlamıştır. O nefsin kemalinin nazarî bilgi dikkate alınmadan gerçekleşemeyeceği kanaatini taşımış, amelî hikmete dair bilginin de derûnunda "nazarî irfân"ın olduğunu düşünmüştür. Nazarî boyuta mukabil işrâkî sûfî,

Sühreverdî, Telvîhâtü'l-levhiyye, 242.

42 Fatma Turğay, “İşrâkî Dil: Sühreverdî' den Şarihlerine İşrâkî Dilin Meşşâi Dile Tercümesi Problemi", Şerhü'l-İ̧râk'ın İzinde: Illk Dönem İşrâkî Şârihler (Ankara: Divan Kitap, 2015), 16.

43 Leys Sâlih Muhammed 'Atûm, el-Felsefetü'l-İşrâkiyye 'inde's-Sühreverdî (İrbid: Âlemü'l-Kütübi'lHadîs, 2015), 2.

44 Râcih Abdulhamîd, Nazariyyetü'l-ma'rife beyne'l-Kur'ân ve'l-felsefe (Riyad: Mektebetü'l-Müeyyed, 1992), 678. 
manevî bir pratik olarak, rûhânî mücâhedesine her zaman devam etmelidir. ${ }^{45}$ Sühreverdî kendi düşüncesini, Hikmetü'l-işrâk adlı kitabında uzun uzadıya ortaya koymaktadır. Farsça kaleme aldığ1 el-Elvâhu'l-'ımâdiyye, Pertevname ve Heyâkilu'n-nûr adlı kitaplarında da görüşlerini ifade etmiştir.

Maşrık ve Mağrib'de birçok İşrâkî filozof, Sühreverdî'yi takip etmiştir. Kuşkusuz bu takipçilerin arasında en meşhur olanlar, İbn Kemmûne (ö. 683/1284), Şemseddîn Şehrezûrî, Kutbeddîn eş-Şîrâzî (ö. 710/1311) ve Celâleddîn ed-Devvânî (ö. 908/1502) gibi kişilerdir. Devvânî'nin Akkoyunlu hükümdarları tarafından itibar görmekle beraber iç karışıklıklar nedeniyle kaçak yaşadığı dönemler olmuştur. Devvânî, II. Bayezid (1481-1512) ile de mektuplaşmış ve onun hediyelerine mazhar olmuştur. Şiraz'da Devvânî'den yedi yıl tahsil gördükten sonra İstanbul'a dönerek II. Bayezid döneminde Anadolu ve Rumeli kazaskerliği de yapmış olan Müeyyedzâde Abdurrahman Efendi (ö. 922/1516) ise İşrâk felsefesinin Osmanlı döneminin önemli temsilcilerindendir. ${ }^{46}$

\section{2. İbnü'l-Arabî}

Metafizik tasavvufun en önemli temsilcisi şüphesiz İbnü'l-Arabî ve onun başlattığ1 Ekberî geleneğidir. Aslında İbnü'l-Arabî'nin çocukluk döneminden itibaren Bâtıni şuhûda derin bir hazırlığa sahip olması, araştırmacılar nezdinde tuhaf karşılanan bir durum olmuştur. ${ }^{47}$ Fakat aslî şuhûd ve irfânî makamlar ve onun ifadesinde ve yorumlarındaki harikulade kudret, günümüze kadar İslâm irfân tarihinde eşi benzeri görülmemiş bir durumdur. Onun vahdet-i vücûdun temel ilkelerini belirlemek hususunda gösterdiği gayreti, vahdet-i vücûd bilgi sistemini şuhûda dayalı düzenli bir sistematiğinin çerçevesinin çizilmesi bakımından en üst seviyeye yükseltmiştir. Bu sistemin yetkin bir biçimde zuhuru, onun öğrencileri ve ileri gelen bazı taraftarlarının eserleri sayesinde olmuştur ki, onun vahdet-i vücûdun bilgi sistemi ile alakalı irfân medresesinin alt yapısı, kuralları ve fürûa dair hususlarla ilgili yekpare bir ilgisi olduğunu ve çeşitli eserlerde bunu dağınık da olsa görmenin mümkün olduğunu söyleyebiliriz. Bu rasyonel aklânî sistemdeki alt yapı, gerekler ve fürû tertibi, bir zamansal döneme ihtiyaç duymuştur ve onun öğrencileri, bunun övgüsüne nail olmuşlardır. Onun eserlerine müracaat edildiğinde, açık bir biçimde varlık meselesi ile ilgili olarak bu mârifet sisteminin genel çerçevesinin mevcudiyeti müşâhede edilir.

45 Havâlidiyye, Sar'a't-tasavouf, 94.

46 Hasan Aksoy, "Müeyyedzâde Abdurrahman Efendi", Türkiye Diyanet Vakfi İslâm Ansiklopedisi (İstanbul: TDV Yayınları, 2006), 31/485.

47 İbnü'l-Arabî'nin çocukluk döneminde İbn Rüşd ile karşılaşması rivayeti için bkz. İbnü'l-Arabî, el-Fütûhâtü'l-Mekkiyye (Beyrut: Dârü İhyâ-i Türâsi'l-Arabî, ty), 1/153. 
Fakat bu potansiyel olarak görülür, fiilî olarak görülemez. Onun için, kaynakların birinde felsefî bir karakterdeki bir iddia veya akli düşüncelere dayalı bir şey ortaya konulup müşâhede edilmemiş, fakat sürekli bir biçimde şuhûdun kaynağına dair bir konuşma yaptığı görülmüştür. Bu sebeple onun akıldan ve felsefeden daha üstün ve daha değerli bir şey görme eğiliminde olduğu söylenebilir. Eserlerinin içeriğinin mülahaza edilmesinden onun kendisine çağdaş olan kelâm ve İslâm felsefesi gibi çok farklı çağdaş geniş bir fikri eğilimi olduğu görülmekle beraber, onun akıl ve felsefeden şuhûdu daha değerli bir şey olarak gördüğü anlaşılır. ${ }^{48}$ Yani İbnü'l-Arabî'nin, kendi döneminde bilinen kelâmî ve felsefî terminolojinin kullanımına dayandığını ve nazarî irfânın terminolojisi için ulaşmış olduğu yeni anlamları ortaya koyduktan sonra yeni bir kamus inşa etmeye yöneldiğini göstermektedir. Kendisinden sonraki taraftarlarının eserlerinde bu iş daha da yetkin hale gelmiştir. Buna İbnü'l-Arabî'nin sahip olduğu parlak zihin yapısı ve varlık epistemolojisi ile ilgili olarak ortaya koymuş olduğu ciddi sorular da eklenmelidir. Bu durum, onun irfânî kurucu medresesini ve ekolünü, sağlam bir felsefî retoriğe dönüştürmüştür. Onun takipçileri bu kuvveti ve potansiyeli işlemişler ve bunu, felsefe ve irfân arasında bir nevi diyalog oluşturabilecek bir çevre kuracak hale getirmişlerdir. ${ }^{49}$

İbnü'l-Arabî'nin vahdet-i vücûd teorisi tasavvuf tarihinde bir dönüm noktası olarak kayıtlara geçmiştir. İbnü'l-Arabî gerçekte kendisi, vahdet-i vücûd tabirini kullanmasa da onun en etkili öğrencisi Sadreddîn Konevî bu terimi en az iki vesileyle kullanmıştır. Daha sonra Konevî'nin öğrencisi Sa îdüddîn elFergânî (ö. 695/1296), İbnü'l-Fâriz'in (ö. 632/1235) Tâiyye'si üzerine yazdığı iki önemli şerhte vahdet-i vücûd terimine birçok kez yer vermiştir. Ama ne Konevî ne de Fergânî, terimi daha sonraki yüzyıllar içinde kazandığı teknik anlamda kullanmışlardır. Bu arada İbn Seb`în (ö. 669/1270) ile Azîzüddîn en-Nesefî (ö. 700/1300) gibi İbnü'l-Arabî okulunun ikinci dereceden belli bazı şahsiyetleri, terimi, sûfîlerin dünya görüşünü dolaylı yollardan anlatmak için kullanmışlardır. Vahdet-i vücûdu, İbnü'l-Arabî'nin doktrinini ifade etmek üzere teknik anlamda ilk kullanan kişi ise İ́nn Teymiyye'dir. ${ }^{50}$

Vahdet-i vücûdun ontolojik sistemi oldukça kısa şekilde şöyle izah edilebilir: Ezelî vahdetten ehadiyyet ve vâhidiyyet çıkmıştır. Bu ikisi arasında bir berzah olmak üzere -tıpkı aşkın, âşık ve maşûk arasında câmi [kapsayıcı ve

48 Penâh, el-ìrfânü'n-nazarî, 30.

49 Osman Yahyâ, Müellefâtü İbn Arabî ve târîhuhâ ve tasnîfuhâ, çev. Ahmed Tayyib (Kahire: Dârü'sSâbûnî, ty), 79.

50 M. Mustafa Çakmaklığlu, İbn Arabî'de Ma'rifetin İfadesi (İstanbul: İnsan Yayınları, 2011), 24. 
ortak] bir kavram olması gibi- iki birlik alanı ortak bir paydada buluşur. Tümel olan, 'ayn-1 vâhidedir. Bu ise Hakk'ın Zâtı'nın aynıdır. ${ }^{51}$

İbnü'l-Arabî'nin külliyatı içerisinde birçok kitap ve risale arasında Fusûsü'l-hikem ve el-Fütûhâtü'l-Mekkiyye'nin büyük önemi vardır. Fütûhâtü̈lMekkiyye, oldukça kapsamlı bir eserdir. İbnü'l-Arabî düşüncesini sistematize ederek -kısa hacmine rağmen- tasavvuf metafiziğinin kurucu metni durumundaki Miftâhü'l-gayb'ın müellifi Sadreddîn el-Konevî'yi de burada anmak gerekir. Miftâhü'l-gayb, tasavvuf metafiziğini, "metodolojisi olan bir ilim" seviyesine yükseltmiştir. ${ }^{52}$ Konevî'nin, Fusûsü'l-hikem'in anlaşılmasında anahtar bir kitap mahiyetinde olan Risâletü'n-nusûs'u, tecellî-i zâtî makamı ile ilgili mârifet konularını muhtevi olması bakımından da yararlı bir çalışmadır. Aynı şekilde onun irfânî tecrübeleri ve mükâşefeyi konu edinen en-Nefehâtü'l-illâhiyye'si burada anılabilir. Bu çerçevede Konevî'nin Miftâhü'l-gayb'1, Muhammed b. Hamza elFenârî'nin Misbâhü'l-üns şerhiyle birlikte mütalaa edilebilir. Elbette İbnü'lArabî'nin çok zengin olan külliyatı arasında Tercümânü'l-eşvâk, ed-Dîvânüll-kebîr, Rûhu'l-kuds, Mevâki'u'n-nucûm ve İnşâü'd-devâir anılabilir. Onun pek çok eseri üzerine yazılmış şerh ve haşiyelerle bu koleksiyon daha da zenginleşmektedir. ${ }^{53}$

\subsection{Molla Sadrâ}

Sühreverdî'nin en önemli takipçilerinden biri Molla Sadrâ eş-Şirâzî'dir. O, İbnü'l-Arabî'nin görüşlerinden de önemli ölçüde etkilenmiştir. Molla Sadrâ, İşrâk felsefesi ekseninde düşünce üretmiş, gerçekten orijinal fikirleri olan ve kendi döneminde İran düşünce felsefesini temsil eden bir kişidir. Asıl adı ile Sadrüddîn Muhammed b. İbrâhîm el-Kavâmî eş-Şîrâzî olan Molla Sadrâ, Fars eyaletinin tarihî şehri Şîrâz' da aristokrat bir ailede dünyaya gelmiştir. ${ }^{54}$

Molla Sadrâ daha sonra Kûm'a gitmiş ve münzevi bir hayatı tercih etmiştir. On beş yıl kadar sürdüğü tahmin edilen uzlet yıllarını, riyâzet ve nefis mücâhedesi ile geçiren Molla Sadrâ'nın eserlerinin telifine dair mükâşefelere bu dönemde nail olduğu ve bu süreçte düşünce sisteminin temel dinamiklerine bir zemin hazırlama fırsatı elde ettiği söylenmektedir. ${ }^{55}$ Molla Sadrâ uzlet sonrası Şîrâz'a dönerek aralarında iki damadı Feyyâz Lâhicî (ö. 1072/1661 [?]) ve Feyz-i

51 Lisânüddîn İbnü'l-Hatîb, Ravdatü't-ta'rîf bi hubbi'ş-şerîf, thk. Muhammed el-Kettânî (Dârü'lBeyzâ: Dârü's-Sekâfe, 2004), 489-490.

52 Penâh, el-írfânü'n-nazarî, 35, 36.

53 Osman Yahyâ, Müellefâtü İbn Arabî, 79.

54 Alî el-Hâc Hasen, el-Hikmetü'l-müte'âliye 'inde Sadri'l-Müteellihîn eş-Şînâzî (Beyrut: Dâru'l-Hâdî, 1326), 13.

55 Alî el-Hâc, el-Hikmetü'l-müte'âliye, 13. 
Kâşânî (ö. 1090/1679) de olmak üzere Molla Hüseyin Tonekabunî ve Hekim Ağacanî gibi öğrenciler yetiştirmiştir. ${ }^{56}$ Meşşâ̂lik, İşrâkîlik ve Ekberîlik ekollerini mezceden Molla Sadrâ, metodunu "Allah'ın lütfu sayesinde biz zevk ve vicdan-1 şuhûdî ile bahs ve burhanı birleştirdik." ${ }^{57}$ şeklinde açıklamaktadır. Bu itibarla Molla Sadrâ kalp, keşif ve müşâhedeyi akıl ve burhana öncelemektedir. Ona göre hikmetin hakikatine, ilm-i ledün sayesinde ulaşılır. Nefis bu mertebeye ulaşmazsa hakîm olunamaz. ${ }^{58}$

Molla Sadrâ, kadim Yunan filozoflarına olumlu yaklaşır. Onların görüşünü tartışır ve bu filozofları geçmiş peygamberler olarak değerlendirir. Molla Sadrâ'ya göre onlar da muvahhittir. ${ }^{59}$ Molla Sadrâ, Kindî (ö. 252/866 [?]), İbnü'1Arâbî, İbn Sînâ, Behmenyâr (ö. 458/1066), Sühreverdî, Nasîruddîn et-Tûsî (ö. 672/1274), Kutbeddîn eş-Şîrâzî ve Mîrdâmâd gibi felsefecilere büyük saygı beslemektedir. Molla Sadrâ özellikle Plotinus, İbn Sînâ, Aristo, İbnü'l-Arabî, Sühreverdî, Râzî, Devvânî ve Mîrdâmâd'dan çok etkilenmiştir. ${ }^{60}$

Molla Sadrâ'nın âlem tasavvuru ve ontolojisinin temelinde teşkîk teorisi bulunmaktadır. Bu teori, varlığı kademeli bir varoluş sürecine bağlamaktadır. ${ }^{61}$ $\mathrm{Bu}$ teorinin daha iyi anlaşılabilmesi için Meşşâi gelenekteki karşılığının bilinmesi gerekmektedir. Meşşâi eğilim a'râz ya da mefhûmda teşkîki (aşamalı bir farklılaşma) kabul eder. İşrâkî eğilim, zâtta ya da mahiyette teşkîki varsayar. Hâlbuki Molla Sadrâ üçüncü bir yol açmış, varlıkta teşkîki asıl kabul etmiştir. ${ }^{62}$ Teşkîkin doğal sonucu olarak vahdet-i vücûd görüşünün aklen ve felsefî olarak teşkîk ile ispat edilebileceği düşünülmüştür. Bu itibarla âriflerin şuhûdunda filozoflardan farklı olarak vahdet-i vücûd, temel bir tefâvüt ve farklılaşma prensibini içinde saklamaktadır. İbnü'l-Arabî, varlığın önceliğinde kesreti benimsemediği gibi; mevcudatta da kesreti vehmedilmiş bir durum olarak görür. Bu doğrultuda İbnü'l-Arabî vücûd ve mevcûdu, yani var olma ve varlığı bir görmekte, ikisi arasındaki tefâvüt ya da farkın türemiş ile türeyişin kaynağı

56 Seyyid Muhammed Hamanei, Molla Sadrâ ve Hikmet-i Müteâliye, çev. Sedat Baran (İstanbul: Denge Yayınları, 2006), 25, 26, 27.

57 Molla Sadrâ, el-Hikmetü'l-müte'âliye fi'l-esfâri'l-akliyye el-erba'a (Beyrut: Dârü İhyâi't-Türâsi'lArabî, 1981), 8/143.

58 Abdü'r-Resûl Ubûdiyyet, en-Nizâmü'l-felsefî li-medreseti'l-hikmeti'l-müte'âliye, çev. Ali Abbas elMûsevî (Beyrut: Merkezü'l-Hadârati'l-Kavmiyye li-Tenmiyeti'1-Fikri'1-İslâmî, 2016), 1/86.

59 Molla Sadrâ, el-Hikmetü'l-müte âliye, 5/206-207.

60 Ubûdiyyet, en-Nizâmü'l-felsefî, 1/55, 61.

61 Ubûdiyyet, en-Nizâmü'l-felsefî, 1/198.

62 Ubûdiyyet, en-Nizâmü'l-felsefi, 1/80-81. 
arasındaki fark gibi olduğunu düşünmektedir. ${ }^{63} \mathrm{Bu}$ görüşleriyle Molla Sadrâ, İbnü'l-Arabî'nin vahdet düşüncesine çok yaklaşmıştır.

\section{5. İBNÜ'L-ARABÎ'NINN DÜŞÜNCE SİSTEMİ VE EKBERÎLİK}

Daha çok bir hürmet ifadesi olarak "eş-Şeyhü'l-Ekber" lakabı ile bilinen İbnü'l-Arabî Endülüs, Mürsiye'de doğmuş, ${ }^{64}$ ömrünün çoğunu Mekke ve Suriye'de geçirmiş ve Şam'da vefat etmiştir. ${ }^{55}$ Asil ve zengin bir ailenin çocuğu olan İbnü'l-Arabî, özel öğretmenlerle yetiştirilmiştir. İbnü'l-Arabî, bizzat elFütûhât'ında anlattığı üzere çocuk denecek yaşta İbn Rüşd (ö. 595/1198) ile görüşmüştür.66

İbnü'l-Arabî, Mağrib (İspanya ve Kuzey Afrika) bölgesinde Ebû Medyen, Ebü'l-Hasen eş-Şâzelî, İbn Seb'în ve İbn Rüşd gibi büyük irfân ve düşünce adamlarının çağdaşıdır. Maşrık (İran, Irak, Anadolu, Şam) bölgesinde ise Abdülkâdir-i Geylânî, Şihâbüddîn Yahya es-Sühreverdî, Şihâbüddîn Ömer esSühreverdî, Necmüddîn-i Kübrâ, Ferîdüddîn Attâr (ö. 618/1221), İbnü'l-Fâriz, Mevlânâ ve Sadreddîn Konevî ile çağdaştır. İbnü'l-Arabî'nin bunların bir kısmı ile hoca öğrenci ilişkisi ya da mülakatı bilinmektedir. O, aynı zamanda Hıristiyan dünyasında Assisli Aziz Fransis (1181-1226), Albertus Magnus (1193-1280), Thomas Aquinas (1224-1274), Yahudi dünyasında ise Moses Maimonides (11351204) gibi şahsiyetlerle de çağdaştır. ${ }^{67}$

Ömrünün sonlarında çeşitli hastalıklarla mücadele etmek zorunda kalmış olan İbnü'l-Arabî, buna rağmen, ilmî faaliyetlerini sürdürmüştür. Hatta o çektiği baş ağrılarına rağmen tıpkı Gazzâlî́nin Tehâfütü'l-felâsife'si tarzında Meşşâi felsefeyi eleştirdiği el-Hikmetü'l-ilhâmiyye'sini yazmış, fizik ve metafizik konularında imâl-i fikir etmeye devam etmiştir. Kendi ifadesi ile teemmül ve nazara ihtiyaç duymadan Allah'ın ilhamına mazhar olmuştur.68 Gerçekten İbnü'l-

63 Gulâm Hüseyin el-İbrâhimî ed-Dînânî, İşrâkü'l-fikr ve'ş-şuhûd fí felsefeti's-Sühreverdî, çev. Abdurrahman el-Alevî (Beyrut: Dârü'l-Hâdî, 2005), 231.

64 Asin Palasios, İbn Arabî hayâtuĥ̂ ve mezhebuĥ̂, çev. Abdurrahman Bedevî (Kahire: Mektebetü'lAngelo el-Misriyye, 1965), 5.

65 Palasios, İbn Arabî, 85, 86.

66 İbnü'l-Arabî, el-Fütûhâtü'l-Mekkiyye, 1/153-154.

67 Stephen Hirtenstein, Hayatı ve Fikriyatıyla Muhyiddin İbn Arabî: "Bir Merhamet Abidesi" (İstanbul: Litera Yayıncilik, 2016), 377-384.

68 Palasios, İbn Arabî, 85. 
Arabî'nin ahir ömrü, ilâhî varidatın yoğun olduğu ve el-Fütûhât ve Fusûsü'lhikem gibi önemli eserler verdiği bir dönemdir. ${ }^{69}$

İbnü'l-Arabî, varlığın oluşumunu eserlerinde Hakîkat-i Muhammediyye'yi merkeze almak suretiyle açıklamaktadır. İbnü'l-Arabî'ye göre “varlık, kün emrinin bir gereği olarak ilâhî nûr sonucu hiyerarşik bir şekilde muhtelif unsurlardan oluşmuştur. Arş, ilâhî kudretin göstergesidir, isimlerinin ve sıfatlarının nişanesi olsun diye Allah varlığı var kılmış sonra [Allah], Levh-i Mahfûz'u, Kalem'i ve Sidretü'l-Müntehâ'yı var etmiştir. Tüm varlık kün kelimesinin iki harfinden, karanlık ve aydınlıktan (ya da zulmet ve nûr'dan) iki unsur hâlinde var edilmiştir." 70 Görüldüğü üzere İbnü'l-Arabî, âlemin yaratılışını Hakîkat-i Muhammediyye'yi ya da Nûr-1 Muhammedî'yi merkeze alarak belli metafizik mertebeler ve hazerât ile ilişkili şekilde anlatmaktadır. Aslında bu düşünceler, onun varlık ve âlem tasavvuru ile ilgili pek çok eserinde ifade edilen düşüncelerin bir özeti mahiyetindedir. Burada geçen pek çok kavram, tasavvuf metafiziğinin varlık ve bilgi ile ilgili temel terminolojisini oluşturduğu gibi Allah'ın âlem ile olan ilişkisini de izah etmektedir. Temelde âlemin ilâhî tecellînin bir mazharı olduğu düşüncesine dayalı bu yaklaşım, bu tecellîde ana mekanizma olan ilâhî isim teorisinin anlaşılmasını gerekli kılmaktadır. İbnü'l-Arabî, varlığı, esmâ-i ilâhiye'nin bir tecellisi olarak görmüş ve doğrudan a'yân-1 sâbite olarak nitelediği ilâhî bir öze bağlamıştır. Bu bakımdan o, varlığı ilâhî varlığın dışında konumlandırmamaktadır. İbnü'l-Arabî tasavvufa ontolojik bir zemin hazırlamış, harf sembolizmi ile bunu daha da derinleştirmiştir. Ona göre harfler de bir âlemdir. Bu görüşleri Konevî, özellikle Miftâhü'l-gayb adlı eseri ile bütüncül bir teorik yapıya dönüştürmüştür. Son tahlilde tasavvuf metafiziğinin İbnü'l-Arabî sayesinde olgunluk dönemine ulaştığı ifade edilmelidir. İbnü'l-Arabî ekolünün, Varlığın Birliği, İnsân-1 Kâmil ve Beş İlâhî Hazret öğretileri, kendisinden sonraki tasavvuf metafiziğinde ciddi izler bırakmıştır. ${ }^{71}$ Burada Dâvûd-i Kayserî ve onun günümüze kadar ilmî mahfillerde okutulan önemli kitaplar arasında yer alan Fusûsu'l-hikem şerhinden bahsedilmesi gerekir. O söz konusu şerhine yaşa-

69 İbnü'l-Arabî'nin Fusûsü'l-Hikem'i nazarî irfân konusunda yazılmış en önemli üç eserden biri olarak gösterilmektedir. Buna göre diğer iki eser, Molla Fenârî'nin Misbâhü̈l-Üns'ü ve Ebû Hâmid Muhammed Türke'nin Kavấidü't-Tevhîd'idir. Abbâs el-Ka'bî, Nazarâtün fi's-sekâfeti'l'irfâniyye (Beyrut: Dârü'l-Meârif el-Hikemiyye, 2017), 104.

70 Osman Nuri Küçük, Fusûsü'l-Hikem ve Mesnevî'de İnsân-ı Kâmil (İstanbul: İnsan Yayınları, 2017), 164.

71 William C. Chittick, "el-Konevî' den el-Kayserî'ye Beş İlâhî Hazret", İbn Arabî Geleneği ve Dâvûd el-Kayser̂̂ (İstanbul: İnsan Yayınları, 2011), 149. 
dığı bir mükâşefeden sonra başlamıştır. Ekolün köşe taşlarının tespit edildiği eser, felsefî sağlamlık ve aklî açıklamalar noktasında eşsizdir.72

İbnü'l-Arabî'nin varlık mertebelerine benzer şekilde, kalbi, manevî, ruhanî, misâlî, hissî ve bunları cemedici mertebe olarak beşe ayırdığı görülür. ${ }^{73}$ Konevî'nin anlatımıyla İbnü'l-Arabî'de Allah'ın emri, yaklaşık olarak iniş ve çıkış seyri içinde şu şekilde gerçekleşir: "Bu gerçekliklerin Gerçekliği (Hakîkatü'l-Hakâik) ile başlar, buna aynı zamanda ilk belirlenim (taayyün-i evvel), her şeyi kuşatıcılık ve varlık hazreti (hazretü'l-cem' ve'l-vücûd) mutlak zâtî taşma (mutlaku'l-feyzi'z-zâtî) denir, bu, bir olan Tanrı'dır. Bu durum Bir'den Bir'in çıkmasıyla olur; çünkü Bir'den ancak Bir çıkar (Lâ yasduru mine'l-vâhid illa'lvâhid). Bu, oluşan varlıklar üzerine taşan Her Şeyi Kuşatıcı Varlık (elvücûdu'l'âm el-mufâd 'alâ a'yâni'l-mükevvenât) olarak bilinir. Tek Sudûr'a genellikle Rahmân'ın Nefesi veya Sis ([Bulut]='Amâ) şeklinde atıfta bulunulur. Bu, sırayla İlk Akıl'la (Yüce Kalem= el-Kalemü'l-A'lâ) başlayarak, âlemi ve Küllî Nefsi (=Korunmuş Levha, el-Levhu'l-Mahfûz) yaratır; bunlardan ikisi rûhânî âlemin sınırlarını çizer. Levh-i Mahfûz ile cismânî dünyanın diş sınırı olan Arş-1 Rahmân (dokuzuncu gök) arasında hayâl âlemi bulunur. Cismânî varlıklar âleminde Emir (el-Kürsiyyü'l-Kerîm'den başlayarak) elementlerin bulunduğu felekler üç melekût boyunca inmeye devam eder. İnsan ile inişin en son sınırına ulaşır. Ondan sonra Berzah Âlemi'ne (ölümle diriliş arasındaki ara bölgeye), dirilişe, cehennem ve cennete, Allah'ın ru'yetine (kâsibu'r-ru'yet) yükselir ve nihayet kaynağıyla, Hakîkatlerin Hakîkati'yle birleşir.74

\section{TASAVVUFî AȘKIN ZİRVE İSIMLERİ MEVLÂNÂ CELÂLEDDÎN-İ RÛMÎ VE ŞEMS-İ TEBRIZÎ}

Mevlânâ'nın kendi irfân düşüncesini oluşturmasında mürşidi ve dostu, Şems'in önemli katkısı vardır. Şems'in hayatı hakkında en eski ve en güvenilir kaynaklardan olan Sultan Veled ve Sipehsâlâr, Şems'in Konya'ya gelişinden önceki hayatına ilgisizdirler. Eflâkî ise Şems'in babasının ve dedesinin adlarının yanı sıra biyografisi ile ilgili birkaç ayrıntıyı da içeren bilgiler vermektedir.

\footnotetext{
Penâh, el-İrfânü'n-nazarî, 42.

73 Sadreddîn Konevî, Fusûsü'l-Hikem'in Sırlarl: el-Fükûk fì Esrârn Müstenidâti Hikemi'l-Fusûs, çev. Ekrem Demirli (İstanbul: İz Yayıncilık, 2012, 12.

74 William C. Chittick, Varolmanın Boyutları Tasavvuf ve Vahdetü'l-Vücûd Üzerine Yazılar, çev. Turan Koç (İstanbul: İnsan Yayınları, 2016), 149; Sadreddin Konevî, Miftâhü'l-Gayb, tsh. Muhammed Hâcevî (Tahran: İntişârâtü Mevlâ, 1374), 271-274; Abdurrahman Câmî, Nefehâtü'l-üns min hadarâti'l-kuds, tsh. Mehdî Tevhîdî Bor (Tahran: İntişârâtü Saîdî, 1366), 81.
} 
Şems'in en karakteristik özelliği yemeden içmeden kesilecek kadar ilâhî aşka boyanmış olmasıdır. Şems-i Tebrîzî, Şems-i Hôyî, Tebrizli Şeyh Ebû Bekir Sellebâf gibi şahsiyetlerden dersler almıştır. ${ }^{75}$

Şems, devrin önemli şahsiyetlerinden hem zahirî ilimleri okumuş hem de irşada tâbi olmuştur. ${ }^{76}$ Aslında Şems'in hocaları ve tarihsel kimliği oldukça tartışmalıdır. Bu doğrultuda Makâlât-ı Şems ilginç kişilikli, şaşırtıcı bir adam olan Şeyh Muhammed'den söz etmektedir. Bu kişi, "kardeş" diye hitap ettiği Şems ile şaşılacak derecede benzer özelliklere sahiptir. Bu kişinin kimliği belirsizdir. Ancak Eflâkî'nin Âriflerin Menkıbeleri kitabının bazı nüshalarında geçen Şam'daki Şeyh Muhammed b. Arabî kaydına dikkat edilecek olursa, anılan bu şahsiyetin, el-Fütühâtü'l-Mekkiyye'nin yazarı meşhur Muhyiddîn İbnü'l-Arabî olduğu düşünülebilir. İbnü'l-Arabî, 1165 yılında muhtemelen Şems'ten yirmi yıl kadar önce, İspanya'da doğmuştur. 1202 ila 1204 yılları arasında Mekke'deydi ve onun orada Selçuklu hükümdarı I. Glyâseddîn Keyhüsrev'in (11921196, 1205-1211) İranlı dostu Mecdüddîn İshâk (ö. 618/1221 [?]) ile görüştüğü bilinmektedir. 1210 yılında İbnü'l-Arabî, Konya'yı ziyaret etmiş ve arkadaşı Mecdüddîn'in vefatı üzerine onun dul eşiyle yani Sadreddîn Konevî'nin annesi ile evlenmiştir. ${ }^{77} \mathrm{Bu}$ bağlamda aslında düşünsel boyut bir tarafa, söz konusu atıflar İbnü'l-Arabî ve Konevî çizgisini Mevlânâ çizgisi ile oldukça yaklaştırmaktadır. Ayrıca Mevlânâ'nın tahsil için gittiği Şam'da görüştüğü Muhyiddîn İbnü'l-Arabî ile hem üvey oğlu hem de öğrencisi Sadreddîn Konevî'nin Mevlânâ üzerindeki doğrudan etkileri yabana atılamaz..$^{78}$

Mevlânâ'nın divanının büyük kısmı Şems ile ilgilidir. Şems'in tasavvuf anlayışının en belirgin hususiyetlerinden biri, melâmet anlayışından kaynaklanan aşk ve cezbeye dayalı bir sülûk anlayışına sahip olmasıdır. Şeklî unsurlardan ziyade sülûk sürecinde sâliki kemâle erdiren asıl unsurun ilâhî aşk olduğu üzerinde duran Şems'in, Mevlânâ'nın hayatına girmesiyle onda uyandırdığı "ilâhî aşk", Mevlânâ'nın manevî gelişim sürecinde ve sülûk anlayışında köklü bir değişim meydana getirmiştir. ${ }^{79}$

75 Franklin Lewis, Mevlânâ: Geçmiş ve Şimdi, Doğu ve Batı Mevlânâ Celâleddin Rûmî'nin Hayatı, Öğretisi ve Şiiri (İstanbul: Kabalcı Yayınları, 2010), 189-189.

76 Lewis, Mevlânâ, 189-189.

77 Lewis, Mevlânâ, 194.

78 Hüseyin Güllüce, “Mevlânâ'nın Düşünce Dünyasının Oluşumunda Etkili Olan Şahsiyetler ve Kaynaklar", Uluslararası Düşünce ve Sanatta Mevlânâ Sempozyumu Bildirileri (Konya: Rûmî Yayınlar1, 2006), 93, 95, 96, 97, 98.

79 Osman Nuri Küçük, Mevlânâ'ya göre Manevî Gelişim (İstanbul: İnsan Yayınları, 2010), 34. 
Kuşkusuz Şems'i ve onun Makâlât'ını tanımadan önce hayatının belli bir bölümünde babası Bahâeddîn Veled'in ve onun Ma'ârif adlı eserinin Mevlânâ üzerinde derin etkisi olmuştur. Mevlânâ'nın babasının, Şeyh Necmeddîn Kübrâ'nın mürid ve halifelerinden olduğu, onun ise Ahmed Yesevî'nin son yıllarına yetişmiş olduğu bilinmektedir. Bu doğrultuda Mevlânâ'nın Necmeddîn Kübrâ'dan ve Ahmed Yesevî'den de faydalandığı ve etkilendiği söylenebilir. ${ }^{80}$

Mevlânâ'nın yararlandığı eserler arasında, Gazneli şair Hakîm Senâî'nin (ö. 525/1131 [?]), Ferîdüddîn Attâr'ın ve Gazzâlî'nin eserleri ile Zemahşerî'nin Keş̧âf'1, İbn Mâlik'in Muvatta'1, Merginânî'nin Hidâye'si, Şehristânî'nin el-Milel ve'n-Nihal'i ve İbn Sînâ'nın el-Kânûn fi't-tıbb'ı bulunmaktadır. O, Sîbeveyh'in elKitâb'1, Câhiz'in (ö. 255/869) el-Beyân ve't-tebyîn'i, Cevherî'nin (ö. 400/1009'dan önce) es-Sihâh'1 ve Meydânî'nin (ö. 518/1124) Mecma'u'l-emsâl'i gibi dilbilimsel ve edebî eserlerden de yararlanmıştır. ${ }^{81}$

Mevlânâ' nın Mesnevî'sinin özü, Şems'e ait Makâlat'ta bulunmakla birlikte, babasının telif ettiği Ma'ârifi i okumadan Mesnevî́nin anlaşılması mümkün değildir. Mesnevî ve Dîvân-ı kebîr'deki bazı hikâye, bahis, mazmun, temsil ve telmihler Ma'ârif de de bulunmaktadır. ${ }^{82}$

Aralarında Hz. Hızır ile Hz. Musa arasındaki gibi bir bağ bulunan Mevlânâ, Şems-i Tebrîzî'nin kayboluşundan sonra onun özlemiyle dile getirdiği coşkun ve heyecanlı şiirleri ile Dîvân-ı kebîr'i meydana getirmiştir. Ne var ki daha sonra, Zerkûbî'nin sohbetleri ve telkinleriyle kendine gelmiş ve en değerli eseri olan Mesnevî́yi yazmaya ve yazdırmaya başlamıştır. Mevlânâ'nın "Dinle, bu ney nasıl şikâyet ediyor." ifadesiyle "İnsân-1 Kâmil"in Hakk'a olan vuslat arzusuyla inlemesi son derece veciz bir tarzda ifadesini bulmuştur. Mevlânâ'ya göre nasıl ki "ney"in içi boştur ve üfleyen kimsenin nefesi ondan ses çıarırsa, İnsân-1 Kâmil'in vücudu da "ney"e benzer. Bu doğrultuda "ney"in yedi deliği, insanın başındaki göz, kulak, burun ve ağız gibi yedi uzvuna işarettir. ${ }^{33}$ Böylece "ney" metaforunda temsil edilen İnsân-1 Kâmil düşüncesi ile bağlantılı olarak dünyada ten kafesinde olmanın huzursuzluğu dile getirilir. ${ }^{84}$ Mevlânâ'ya göre varlığın, varlık katmanlarındaki en mükemmel yansıması insandır. İnsan bilinmeden Yüce Yaratıcı bilinemez. Kendini tanımayan Rabb'ini tanıyamaz [Men

\footnotetext{
Sultan Veled, İbtidânâme (Konya: Konya Turizm Derneği, 1976), 247-248.

Güllüce, "Mevlânâ", 93, 95, 96, 97, 98.

82 Güllüce, "Mevlânâ", 92, 93.

83 Bayram Ali Çetinkaya, "Mevlâna Öğretisinde Müzik ve Ney", Uluslararası Düşünce ve Sanatta Mevlana Sempozyumu (Konya: Rûmî Yayınları, 2006), 694.

84 Metin İzeti, “Mesnevî Perspektifinde İnsân-1 Kâmil Paradigması", Uluslararası Düşünce ve Sanatta Mevlânâ Sempozyumu (Konya: Rûmî Yayınları, 2006), 381.
} 
arefe nefsehu fekad arefe rabbehu]. Burada kendini bilen insandan maksat, İnsân-1 Kâmil' dir. ${ }^{85}$

Mevlânâ açısından yaratılış, tek bir göz kamaştırıcı beyazlığın, yani Allah'ın çok renkli ve çok biçimli tecellisidir. Yaratılış bu ezelî renksizliğin surete ve yönlere saçılması, bu arada tekilleşme, ayrılma, ayrışma ve karşıtlık yanılsamasının doğmasıdır. Mevlânâ, Pers saraylarına özgü bir oyun olan çevgen benzetmesini kullanarak Allah'ın ol emriyle tıpkı çevgenle vurulan top gibi hem mekân âleminde hem de lâmekân âleminde yuvarlanıp durduğumuzu kabul eder. Yaratılışın gözle görülür renkleri arasına fırlatılarak, bize çatışma ve tezatlık getiren özelliklerle boyanırız. ${ }^{86} \mathrm{O}$, "Renksizlik âlemi, renge esir olunca bir Musa, öbür Musa'yla savaşa düştü, Renksizlik âlemine ulaşırsan Musa ile Firavun'un karıştığ âleme erişirsin. ${ }^{87 \prime \prime}$ der. Mevlânâ'ya göre renksizlik, tüm renklerin köküdür.

Sûfî düşünce geleneği doğrultusunda İbnü'l-Arabî ve Mevlânâ, varoluşu gizli hazine kabul edilen Hakk'ın sayısız sıfat ve isimlerindeki kemâlâtın zuhura geliş süreci olarak görmektedir. Mevlânâ'ya göre insan çok değerli bir varlık olarak Rahmânî nefesin mazharı olarak füsun-ı Îsâ nitelemesine layık bir varlıktır. ${ }^{88}$ Mevlânâ varoluşu İbnü’l-Arabî gibi tasavvufî düşünce geleneğindeki "gizli hazine (kenz-i mahfî) anlayışı doğrultusunda izah eder. Âlem, gizli hazine kabul edilen Allah'ın Zât'ındaki içkin ilâhî isim ve sıfatların zuhura gelişidir. Mevlânâ'ya göre, insanın canının canı olduğunu bildiren ilâhî nûr aynı zamanda Muhammedî nûr'dur. ${ }^{89}$ Dolayısıyla Mevlânâ'nın düşüncesinde Nûr-1 Muhammedî ya da başka bir deyişle Hakîkat-i Muhammediye teorisi temel bir teoridir.

Mevlânâ Celâleddîn-i Rûmî insanı merkeze alan ilâhî bir aşk metafiziği geliştirmiş, başta Mesnevî'si ve Dîvân-ı kebîr'i olmak üzere, Rubâiyât, Fîhi mâ fîh, Mecâlis-i seb'a ve Mektûbât gibi eseriyle bu aşkı dile getirmiştir. Mevlevîlik bugün dahi Mevlânâ'nın eserleri, semâ ayini ve Mevlevîliğin kendine özgü musiki, remz ve uygulamaları ile dünyanın çeşitli yerlerinden insanları Mevlânâ'nın terennüm ettiği ilâhî aşka çekmektedir.

85 Mahmud Erol Kılıç, "Sûfî Şiirinin Poetikası", Uluslararası Düşünce ve Sanatta Mevlânâ Sempozyu$m u$ (Konya: Rûmî Yayınları, 2006), 691.

86 Lewis, Mevlânâ, 460.

87 Mevlânâ, Mesnevî, 1/2467-8.

88 Küçük, İnsân-ı Kâmil, 25, 110.

89 Küçük, İnsân-ı Kâmil, 135, 139. 


\section{TASAVVUFU BESLEYEN TEORİLER VE İSLÂM DÜŞÜNCESİNDEKİ YANSIMALARININ GENEL DEĞERLENDİRMESİ}

Tasavvufî düşünce geleneğinde tasavvufun metodolojisini belirleyecek tarzda birçok teori ortaya konmuştur. Bu teoriler dikkate alındığında tasavvufun, salt zühd ile ilişkili bir alandan ibaret olmayıp, epistemolojik, ontolojik, etik ve eskatolojik eksende, felsefe ve kelâm alanlarıyla kesişen fakat kendine özgü bir paradigma inşa ettiği görülür. Bu paradigma, çoğunlukla vahyi kendine referans almış olsa da tabiatı gereği derin senkretik bağlantılar içerir. Bu doğrultuda erken dönemde Bâyezîd-i Bistâmî'nin fenâ teorisi, Ebû Sa'îd elHarrâz'ın (ö. 277/890 [?]) fenâ ve bekâ teorisi, Cüneyd-i Bağdâdî'nin fenâ ve misak nazariyesi ve Elest düşüncesi, Hakîm et-Tirmizî'nin (ö. 320/932) hatmü'1velâye ve inayet görüşü gibi kuramsal bir yapının varlığından söz edilmelidir. Ayrıca ilâhî aşk metafiziği bağlamında Hallâc-1 Mansûr'un (ö. 309/922) lâhûtnâsût ve hulûl teorileri ve 'aynü'l-cem' iddiası ${ }^{90}$ gibi görüşlerinin, tasavvuf düşüncesinde muhtelif yansımaları olmuştur. Benzer şekilde Fârâbî̀nin (ö. 339/950) ittisâl teorisinin ve bilahare İbn Sînâ'nın nefis teorisinin farklı tonlarda tasavvuf düşüncesinde etkileri söz konusudur. Elbette İbn Sînâ'dan çokça etkilenmiş bir kişi olan Sühreverdî gerek İbn Sînâ'nın görüşlerini gerekse Avesta edebiyatı, kadim İran felsefesi ve Hermetik gelenek gibi unsurları mezceden bir anlayışla işrâk ve nûr teorilerini geliştirmiştir. Bu teoriler bir yönüyle varlık problemine çözüm getirmeye çalışırken, diğer taraftan mârifet olgusunun ne olduğunu ortaya koymaya çalışmaktadır.

Tasavvufun erken döneminde görülen fenâ teorisi ise, her şeyden önce dervişin seyr u sülûkunda şahit olduğu bir hâldir. Bu noktada mücâhede ve riyâzet ile sıkı bir bağı vardır. Nefsin tezkiyesi ve arınması hâli olan fenâ, bekâ'nın zıddı olup insanın kötü sıfatlardan sıyrılmasını ifade eder. Fenâ'nın iki tezâhüründen biri, onun temelde çokça yapılan bir riyâzetin sonucunda gerçekleşmesi, diğer tezâhürü ise sâlikin, mülk ve melekût âlemine yönelik idrak ve hissiyattan geçerek tam bir istiğrak hâli içerisinde Hak Teâlâ'yı müşahede etmesidir. Fenâ fillâh'taki sûfî davranışı, fenâ (annihilation) kavramının kendi dinamiği içinde bir eylem olarak sâlikin ilâhî aşkta kendinden geçmesini ifade ederken, fenâ kavramının diğer açıdan, bekâ (permanence) ile ilişkilidir. Bu ikinci eylem şekli, sâlik'in, Zât-1 İlâhiye'nin hakikatine ulaşma idraki içerisinde ikilikten sıyrıldığını ona hissettirir. Birinci eylem türü daha çok, Kuşeyrî, Cü-

90 "Birliğin Özü" diye ifade edilebilecek 'aynü'l-cem', Ben ve Sen'in yani mistik ile ardığ ilâhî objenin tek bir şey hâline gelmesi demektir. Mâcid Fahrî, Târîhu'l-felsefeti'l-İslâmiyye, 117. 
neyd-i Bağdâdî ve Gazzâlî ile ilişkilendirilirken, diğer eylem biçimi Bâyezîd-i Bistâmî, Hallâc-1 Mansûr ve İ̉bnü'l-Arabî ile ilişkili görülür. ${ }^{91}$

Nihayet pek çok tasavvuf tarihçisi açısından ahlâk ve bilgi probleminin çok ötesinde ontolojik bir yaklaşımla kapsamlı bir teori ortaya koyması sebebiyle İbnü'l-Arâbî, tasavvuf alanında en yetkin teorisyen olarak anılmıştır. Ne var ki İbnü'l-Arabî'nin vahdet-i vücûd nazariyesinden önce hiçbir teorinin geliştirilmediği iddiası, -onunki kadar kapsamlı olmasa bile- kronolojik olarak ondan önce yaşamış olan birtakım sûfîlerin teorilerini yok saymak olur. Bu doğrultuda İbnü'l-Arabî'nin vahdet-i vücûd nazariyesinin en önemli referans noktalarından birinin, İbn Kasî̀nin ilâhî isim teorisi olduğu unutulmamalıdır. Gerek ilâhî isim teorisi, gerekse de ism-i a'zam tartı̧̧malarından soyutlanmış bir vahdet-i vücûd teorisi düşünülemez.

Ayrıca bu teorinin temel bileşenleri arasında velâyet teorisi ve Hakîkat-1 Muhammediyye ya da başka bir deyişle Nûr-1 Muhammedî teorisi gibi teoriler bulunmaktadır. Kuşkusuz İbnü'l-Arabî'nin, Mutezile'nin ma'dûm teorisine karşıt geliştirdiği a'yân-1 sâbite teorisi ise onun ontolojisinin oldukça önemli bir yönünü temsil eder. ${ }^{92} \mathrm{Bu}$ öz, Allah'ın sürekli var edişinin bir temsilidir ve Kenzi Mahfî hadisi ile güçlü bir bağlantı içerisinde anlaşılabilir. Bu ise İbnü'1Arabî'nin, kendinden önceki kuramsal yaklaşımları, tahlil, tenkit ve yeniden biçimlendirme eğilimine yönelik ciddi bir kanıt niteliğindedir. İbnü'l-Arabî'nin yukarıda ifade edilen vahdet-i vücûd teorisinin yanı sıra tenzih ve teşbih dikotomisi, harfler âlemi ve ilâh-1 mu'tekad teorileri bu kuramsal çerçevenin girift ve bir o kadar kapsamlı bir varlık ve bilgi tasavvuru olduğunu ispatlar niteliktedir. ${ }^{93}$

\section{SONUÇ}

Teosofik düşüncenin gerçekten en derin irfân modelini, İbnü'l-Arabî ve onun öncülüğünde Sadreddîn Konevî gibi öğrencileri ortaya koymuşlardır. Ne var ki bu teori ile eş zamanlı ya da daha sonra ortaya konmuş ve birçok yönden birbirleriyle bağlantılı teorilerin varlığı inkâr edilemez. Üstelik bu teoriler, sa-

91 Muhammed el-Munsif İbnü'l-Beşîr, Felsefetü İbn Arab̂̂ fi'l-ma'rifeti ve'l-vücûd (İrbid: Âlemü'lKütübi'l-Hadîs, 2016), 189, 191.

92 İbnü'l-Beşîr, Felsefetü İbn Arabî, 258.

93 İbnü'l-Arabî'nin modeline benzer şekilde Molla Sadrâ'da da teşbih ve tenzih dikotomisi bulunmaktadır. Molla Sadrâ'ya göre "tenzîh ve takdîs, ehadiyyet makamına dayanmaktadır. Teşbîh ise kesret ve ma'lûliyyet makamları ile ilişkilidir. Bütün bu övgüye yaraşır makamlar Allah'ın ehadî yönünün farklı ifadeleridir. Molla Sadrâ, el-Hikmetü'l-mütéâliye, 6/374. 
dece tasavvufun kendi dinamikleriyle de açıklanamayacak kadar farklı düşünsel yapılarla irtibatlı görünmektedir. Bu noktada tasavvuf, kelâm ve felsefenin, bir tedahül oluşturacak şekilde benzer parametreleri kendi metodolojileri içerisinde şekillendirdikleri söylenebilir. Bu nazarî teşekkül süreci aynı zamanda interdisipliner bir etkileşim sürecidir. Örneğin tasavvuf düşüncesini etkilemiş olan feyz nazariyesi Platon temelli bir referans zemine sahiptir. Bu teori Aristo'nun düşünce dünyasına uymaz. Tasavvuf, İbn Sînâ üzerinden etkilendiği öngörülebilecek şekilde feyz nazariyesinden kendi neşvesi içerisinde yararlanmıştır. ${ }^{94} \mathrm{Ne}$ var ki pek çok sûfî, tıpkı Yunus Emre'nin Divân-ı İlâhiyât'ında açıkça görüldüğü gibi Aristo'nun Anâsır-1 Erba'a düşüncesinden de beslenir. ${ }^{95}$

Tasavvufun farklı tezâhür ve meşrepler ile bağlantılı olduğu kabul edilmelidir. Bu doğrultuda vahdet-i vücûda aldığı pozisyon itibarıyla daha net konumlandırabileceğimiz ve İmâm Rabbânî'nin (ö. 1034/1624) vahdet-i şuhûd teorisi ve İşrâkî gelenek içerisinde İbnü'l-Arabî'nin düşünce dünyasına oldukça yaklaşan Molla Sadrâ'nın vahdet-i sinhiyye yorumu ve teşkîk teorisi, -birtakım benzerliklerine rağmen- önemli ölçüde farklılıklar içeren tasavvufî yaklaşımlardir.

Fârâbî ve İbn Sînâ'nın feyz ve sudûr teorileri bağlamında ya da Anâsır-1 Erba'a gibi kozmogonik yaklaşımlarının, şu ya da bu şekilde varlık ve bilgi konusunda söyleyecek çok şeyi olan tasavvufta etkisinin olması yadırganacak bir durum değildir. Özellikle tasavvufun nazarî irfân boyutu açısından bilginin İslâmîleştirilmesi sürecinde bu menkul bilgi unsurları, nassî tevillere konu olacak şekilde içselleştirilmiştir.

\section{KAYNAKÇA}

Abdulhamîd, Râcih. Nazariyyetü'l-ma'rife beyne'l-Kur'ân ve'l-felsefe. Riyad: Mektebetü'l-Müeyyed, 1992.

Aksoy, Hasan. "Müeyyedzâde Abdurrahman Efendi". Türkiye Diyanet Vakfı İslâm Ansiklopedisi. 31/485-486. İstanbul: TDV Yayınları, 2006.

Atûm, Leys Sâlih Muhammed. el-Felsefetü'l-İşrâkiyye 'inde's-Sühreverdî. İrbid: Âlemü'l-Kütübi'l-Hadîs, 2015.

Bâlî, Mirvet İzzet. İtticâhü'l-İşrâkî, fî felsefeti İbn Sînâ. Beyrut: Dârü'l-Ĉ̂l, 1414/1994.

94 Cemîl Salîba, Min Eflâtûn ilâ İbn Sînâ (Beyrut, Dâru'l-Endelüs, 1951), 84-85.

95 Abdülbaki Gölpınarlı, Yunus Emre Hayatı ve Bütün Şiirleri (İstanbul: Altın Kitaplar Yayınevi, 1973), 239. 
Bedevî, Abdurrahmân. Şahsiyyât kalika fi'l-İslâm. Beyrut: el-Merkezü'l-Akâdîmî, li'lEbhâs, 2015.

Câmî, Abdurrahman. Nefehâtü'l-üns min hadarâti'l-kuds. tsh. Mehdî Tevhîdî Bor. Tahran: İntişârâtü Saîdî, 1366

Chittick, William C. “el-Konevî'den el-Kayserî’ye Beş İlâhî Hazret”. İbn Arabî Geleneği ve Dâvûd el-Kayserî. İstanbul: İnsan Yayınları, 2011.

Chittick, William C. Varolmanın Boyutları Tasavvuf ve Vahdetü'l-Vücûd Üzerine Yazılar. çev. Turan Koç. İstanbul: İnsan Yayınları, 2016.

Corbin Henry. Bir'le Bir Olmak: İbn Arabî Tasavvufunda Yaratıcı Muhayyile. çev. Zeynep Oktay. İstanbul: Pinhan Yayınları, 2015.

Corbin, Henry. el-Hayâlu'l-Hallâk fî tasavvufi İbn Arabî. çev. Ferîd ez-Zâhî. BağdatKöln: Menşûrâtü'l-Cemel, 2008.

Corbin, Henry. İslâm Felsefesi Tarihi: İbni Rüşd'ün Ölümünden Günümüze. çev. Ahmet Arslan. İstanbul: İletişim Yayınları, 2017.

Cürcânî, Seyyid Şerîf. Kitâbu't-ta'rîfât: Arapça-Türkçe Terimler Sözlüğü. çev. Ali Erkan. İstanbul: Bahar Yayınları, 1997.

Çakmaklığlu, M. Mustafa. İbn Arabî'de Ma'rifetin İfadesi. İstanbul: İnsan Yayınları, 2011.

Çetinkaya, Bayram Ali. "Mevlâna Öğretisinde Müzik ve Ney". Uluslararası Düşünce ve Sanatta Mevlana Sempozyumu. Konya: Rûmî Yayınları, 2006.

Demirli, Ekrem. “Gazzâli ve Tasavvuf”. Gazzâlî Konuşmaları. İstanbul: Küre Yayınları, 2012.

Demirli, Ekrem. İbnü'l-Arabî Metafiziği. İstanbul: Sûfî Kitap, 2013.

Demirli, Ekrem. Sadreddin Konevî’de Bilgi ve Varlık. İstanbul: İz Yayıncılık, 2011.

Demirli, Ekrem. Tasavvufun Altın Çağı: Konevî ve Takipçileri. İstanbul: Sufi Kitap, 2015.

Dînânî, Gulâm Hüseyin el-İbrâhimî. İşrâkü'l-fikr ve'ş-şuhûd fî felsefeti's-Sühreverdî. çev. Abdurrahman el-Alevî. Beyrut: Dârü'l-Hâdî, 2005.

Ebû Reyyân, Muhammed Alî. Usûlü'l-felsefeti'l-İşrâkiyye inde's-Sühreverdî. Beyrut: Dârü'n-Nahdati'l-Arabiyye, ty.

Fahrî, Mâcid. Târîhu'l-felsefeti'l-İslâmiyye. Beyrut: ed-Dâru'l-Muttehide li'n-Neşr, 1974.

Gazzâlî, Ebû Hâmid. Mişkâtü'l-envâr ve misfâtü'l-esrâr. thk. Abdülaziz İzzüddîn esSeyravân. Beyrut: Âlemü'l-Kütüb, 1407/1986.

Gölpınarlı, Abdülbaki. Yunus Emre Hayatı ve Bütün Şiirleri. İstanbul: Altın Kitaplar Yayınevi, 1973.

Güllüce, Hüseyin. “Mevlânâ'nın Düşünce Dünyasının Oluşumunda Etkili Olan Şahsiyetler ve Kaynaklar". Uluslararası Düşünce ve Sanatta Mevlânâ Sempozyumu Bildirileri. 85-99. Konya: Rûmî Yayınları, 2006.

Hamanei, Seyyid Muhammed. Molla Sadrâ ve Hikmet-i Müteâliye. çev. Sedat Baran. İstanbul: Denge Yayınları, 2006. 
280 • Metafizik Dönem Ekseninde Tasavvufun Teorik Yapısına Dair Doksografik Bir Değerlendirme

Hanbelî, İbnü'1-İmâd. Şezerâtü'z-zeheb fî ahbâri men zeheb. Kahire: Mektebetü'l-Kudsî, 1350.

Hasen, Alî el-Hâc. el-Hikmetü'l-müte'âliye 'inde Sadri'l-Müteellihîn eş-Şîrâzî. Beyrut: Dâru'l-Hâdî, 1326.

Havâlidiyye, Esmâ. Sar'a't-tasavvuf, el-Hallâc ve 'Aynu'l-Kudât el-Hemezânî ve'sSühreverdî nemâzice: dirâsetün tahlîliyye nakdiyye mukârene testelhimu mefâhîme nazariyyeti't-takabbül. Rabat: Dâru'l-Emân, 1435/2014.

Hirtenstein, Stephen. Hayatı ve Fikriyatıyla Muhyiddin İbn Arabî: “Bir Merhamet Abidesi". İstanbul: Litera Yayıncılık, 2016.

İbn Hallikân, Ebü'l-Abbâs Şemsüddîn Ahmed. Vefeyâtü'l-a'yân. thk. İhsan Abbas. Beyrut: Dârü Sâdır, ty.

İbn Sînâ. Risâle fi'l-'1şk. thk. Hüseyin es-Sıddîk-Râviye Câmûs. Dımaşk: Dâru'l-Fikr, 2005.

İbnü'l-Arabî. el-Fütuhâtü'l-Mekkiyye. thk. Osman Yahya-İbrahim Medkûr. Kahire: elHey'etü'l-Misriyye, 1985.

İbnü'1-Beşîr, Muhammed el-Munsif. Felsefetü İbn Arabî fi'l-ma'rifeti ve'l-vücûd. İrbid: Âlemü'l-Kütübi'l-Hadîs, 2016.

İbnü'l-Hatîb, Lisânüddîn. Ravdatü't-ta'rîf bi hubbi'ş-şerîf. thk. Muhammed el-Kettânî. Dârü'l-Beyzâ: Dârü's-Sekâfe, 2004.

İzeti, Metin. "Mesnevî Perspektifinde İnsân-1 Kâmil Paradigması". Uluslararası Düşünce ve Sanatta Mevlânâ Sempozyumu. Konya: Rûmî Yayınları, 2006.

Ka'bî, Abbâs. Nazarâtün fi's-sekâfeti'l-'irfâniyye. Beyrut: Dârü'l-Meârif el-Hikemiyye, 2017.

Kartal, Abdullah. Tasavvufun Oluşumu Şeriat-Hakîkat İlişkisi. Bursa: Emin Yayınları, 2015.

Kılıç, Mahmud Erol. "Sûfî Şiirinin Poetikası". Uluslararası Düşünce ve Sanatta Mevlânâ Sempozyumu. 690-700. Konya: Rûmî Yayınları, 2006.

Knysh, Alexander D. Ibn Arabī in The Later Islamic Tradition The Making of a Polemical Image in Medieval Islam. New York: State University of New York Press, 1999.

Konevî, Sadreddîn. Fusûsü'l-Hikem'in Sırları: el-Fükûk fî Esrârı Müstenidâti Hikemi'1Fusûs. çev. Ekrem Demirli. İstanbul: İz Yayıncılık, 2012.

Konevî, Sadreddîn. Miftâhü'l-Gayb. tsh. Muhammed Hâcevî. Tahran: İntişârâtü Mevlâ, 1374.

Kutluer, İlhan. "Hikmetü'l-İşrâk". Diyanet Vakfı İslâm Ansiklopedisi. 17/522. İstanbul: TDVY, 1998.

Küçük, Osman Nuri. Fusûsü'l-Hikem ve Mesnevî'de İnsân-1 Kâmil. İstanbul: İnsan Yayınları, 2017.

Küçük, Osman Nuri. Mevlânâ'ya göre Manevî Gelişim. İstanbul: İnsan Yayınları, 2010. 
Lewis, Franklin. Mevlânâ: Geçmiş ve Şimdi, Doğu ve Batı Mevlânâ Celâleddin Rûmî’nin Hayatı, Öğretisi ve Şiiri. İstanbul: Kabalcı Yayınları, 2010.

Molla Sadrâ. el-Hikmetü'l-müte'âliye fi'l-esfâri'l-akliyye el-erba'a. Beyrut: Dârü İhyâi'tTürâsi'l-Arabî, 1981.

Osman Yahyâ. Müellefâtü İbn Arabî ve târîhuhâ ve tasnîfuhâ. çev. Ahmed Tayyib. Kahire: Dârü's-Sâbûnî, ty.

Palasios, Asin. İbn Arabî hayâtuhû ve mezhebuhû. çev. Abdurrahman Bedevî. Kahire: Mektebetü'l-Angelo el-Misriyye, 1965.

Penâh, Yedullah Yezdân. el-İrfânü'n-nazarî mebâdiuhû ve usûluhû. çev. Alî Abbâs elMûsevî. Beyrut: Merkezü'l-Hadâre li't-Tenmiyeti'l-Fikri'l-İslâmî, 2016.

Salîba, Cemîl. Min Eflâtûn ilâ İbn Sînâ. Beyrut, Dâru'l-Endelüs, 1951.

Sultan Veled. İbtidânâme. Konya: Konya Turizm Derneği, 1976.

Sühreverdî, Şihâbüddîn. et-Telvîhâtü'l-levhiyye ve'l-'arşiyye. nşr. Necefkulî Habîbî. Tahran: Iranian Institute of Philosofy, 2009.

Tek, Abdurrezzak. Tarihi Süreçte Tasavvuf ve Tarikatlar. Bursa: Bursa Akademi, 2016.

Turğay, Fatma. “İşrâkî Dil: Sühreverdî’den Şarihlerine İşrâkî Dilin Meşşâi Dile Tercümesi Problemi”. Şerhü'l-İşrâk'ın İzinde: İlk Dönem İşrâkî Şârihler. Ankara: Divan Kitap, 2015.

Ubûdiyyet, Abdü'r-Resûl. en-Nizâmü'l-felsefî li-medreseti'l-hikmeti'l-müteâliye. çev. Ali Abbas el-Mûsevî. Beyrut: Merkezü'l-Hadârati'l-Kavmiyye li-Tenmiyeti'lFikri'l-İslâmî, 2016.

Veysî, Yasin Hüseyin. es-Sühreverdî el-İşrâkî ve nakduhû li'l-felsefeti'l-Yûnâniyye. D1meşk: Dârü Ninova, 2007.

Zerrinkub, Abdulhüseyin. Tarihsel Perspektifiyle İran Tasavvufu. çev. Nurcan Altun. İstanbul: Önsöz Yayıncilık, 2014. 